\title{
The Genetic Component of Seagrass Restoration: What We Know and the Way Forwards
}

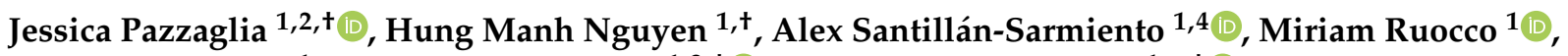 \\ Emanuela Dattolo ${ }^{1}$, Lázaro Marín-Guirao ${ }^{1,3, \neq(1)}$ and Gabriele Procaccini ${ }^{1, *, \ddagger \mathbb{D}}$ \\ 1 Department of Integrative Marine Ecology, Stazione Zoologica Anton Dohrn, 80121 Napoli, Italy; \\ jessica.pazzaglia@szn.it (J.P.); hung.nguyen@szn.it (H.M.N.); alex.santillan@szn.it (A.S.-S.); \\ miriam.ruocco@szn.it (M.R.); dattolo@szn.it (E.D.); lazaro.marin@ieo.es (L.M.-G.) \\ 2 Department of Life Sciences, University of Trieste, 34127 Trieste, Italy \\ 3 Seagrass Ecology Group, Oceanographic Centre of Murcia, Spanish Institute of Oceanography, C/Varadero, \\ 30740 San Pedro del Pinatar, Spain \\ 4 Faculty of Engineering, National University of Chimborazo, Riobamba 1407, Ecuador \\ * Correspondence: gpro@szn.it; Tel.: +39-081-5833363 \\ + These authors have contributed equally to the work. \\ $\ddagger$ These authors have contributed equally to the work.
}

Citation: Pazzaglia, J.; Nguyen, H.M.; Santillán-Sarmiento, A.;

Ruocco, M.; Dattolo, E.;

Marín-Guirao, L.; Procaccini, G. The Genetic Component of Seagrass Restoration: What We Know and the Way Forwards. Water 2021, 13, 829. https://doi.org/10.3390/w13060829

Academic Editor: Sebastiano Calvo

Received: 12 February 2021

Accepted: 15 March 2021

Published: 18 March 2021

Publisher's Note: MDPI stays neutral with regard to jurisdictional claims in published maps and institutional affiliations.

Copyright: () 2021 by the authors. Licensee MDPI, Basel, Switzerland. This article is an open access article distributed under the terms and conditions of the Creative Commons Attribution (CC BY) license (https:// creativecommons.org/licenses/by/ $4.0 /)$.

\begin{abstract}
Seagrasses are marine flowering plants providing key ecological services and functions in coasts and estuaries across the globe. Increased environmental changes fueled by human activities are affecting their existence, compromising natural habitats and ecosystems' biodiversity and functioning. In this context, restoration of disturbed seagrass environments has become a worldwide priority to reverse ecosystem degradation and to recover ecosystem functionality and associated services. Despite the proven importance of genetic research to perform successful restoration projects, this aspect has often been overlooked in seagrass restoration. Here, we aimed to provide a comprehensive perspective of genetic aspects related to seagrass restoration. To this end, we first reviewed the importance of studying the genetic diversity and population structure of target seagrass populations; then, we discussed the pros and cons of different approaches used to restore and/or reinforce degraded populations. In general, the collection of genetic information and the development of connectivity maps are critical steps for any seagrass restoration activity. Traditionally, the selection of donor population preferred the use of local gene pools, thought to be the best adapted to current conditions. However, in the face of rapid ocean changes, alternative approaches such as the use of climate-adjusted or admixture genotypes might provide more sustainable options to secure the survival of restored meadows. Also, we discussed different transplantation strategies applied in seagrasses and emphasized the importance of long-term seagrass monitoring in restoration. The newly developed information on epigenetics as well as the application of assisted evolution strategies were also explored. Finally, a view of legal and ethical issues related to national and international restoration management is included, highlighting improvements and potential new directions to integrate with the genetic assessment. We concluded that a good restoration effort should incorporate: (1) a good understanding of the genetic structure of both donors and populations being restored; (2) the analysis of local environmental conditions and disturbances that affect the site to be restored; (3) the analysis of local adaptation constraints influencing the performances of donor populations and native plants; (4) the integration of distribution/connectivity maps with genetic information and environmental factors relative to the target seagrass populations; (5) the planning of longterm monitoring programs to assess the performance of the restored populations. The inclusion of epigenetic knowledge and the development of assisted evolution programs are strongly hoped for the future.
\end{abstract}

Keywords: seagrasses; restoration; genetic diversity; donor sites; transplantation; provenance; monitoring 


\section{Introduction}

Global climate change, along with local disturbances, are enhancing habitat degradation and biodiversity loss at an alarming rate and extension that is comparable only with past mass-extinction events [1]. Historically, restoration science has played a crucial role in the recovery of ecosystem properties and functions. However, with the current acceleration of environmental degradation, traditional restoration practices may no longer be sufficient [2,3]. Ecological restoration has become a major focus of conservation and natural resource management, as well as a strategy that can potentially provide realistic, context-specific pathways to a sustainable future. A meta-analysis estimated that global restoration practices had increased the provision of biodiversity and ecosystem services by an average of $25 \%-44 \%$ of what had been degraded [4], and some ecosystem services did recover with the success of restoration activities [5]. However, the restoration of marine ecological systems (including seagrasses) is still underdeveloped compared to terrestrial environments [6]. Although progress in restoration has been achieved for important marine ecosystems such as coral reefs, kelp forests, and seagrasses [7-10], the genetic research required for a proper restoration plan is not always applied, remaining more as a theoretical assumption rather than a practical action. In addition, legal issues on how to manage the genetic component of restoration are unclear [3,11].

Seagrasses are marine flowering plants that form extensive meadows in temperate and tropical waters of all continents except for Antarctica [12]. These meadows provide key ecological functions and ecosystem services to coastal areas and human livelihoods [13,14], ranking among the most valuable ecosystems on Earth along with coral reefs and tropical rainforests [15]. Seagrasses reproduce both clonally and sexually, these two strategies being dependent on external environmental conditions and internal cues [16-19]. Sexual reproduction ensures the rise of new genetic variants and boosts the plastic response of genotypes and populations to environmental changes [20]. Nevertheless, clonal (vegetative) propagation also plays a crucial role in the existence of seagrass species, contributing to important advantages, such as the colonization of vast areas and resource/risk sharing under unfavorable conditions [21-24]. In some species, sexual reproduction infrequently occurs, thus negatively affecting genetic diversity distribution within and among populations [25-27].

The decline of seagrass meadows reported in several regions of the world following extreme climate events (e.g., marine heatwaves and/or storms) is expected to occur more frequently in the coming decades $[28,29]$. It has been estimated that at least $1.5 \%$ of seagrass meadows are lost every year, and nearly $29 \%$ of their areal extent has disappeared since 1879 [30]. On the IUCN's Red List (International Union for Conservation of Nature), 24\% of seagrass species have been classified as either 'threatened' or 'near-threatened' [31]. The concurrent action of local and global stressors is impacting seagrass performances [32,33], consequently affecting associated organisms and communities [34] as well as goods and services provided by them [13]. In the light of accelerated decline, restoration has become a priority strategy to slow-down seagrass degradation and to repopulate degraded meadows, thus protecting and ultimately recovering their ecosystem functions and services $[5,8]$. The survival of restored populations will strongly depend on future climatic events, which could jeopardize the heavy investment in time and money associated with restoration programs. This situation is currently opening a debate of whether to restore coastal vegetation-based ecosystems to historical baselines or to use a restoration to facilitate adaptation to climatic scenarios expected in the future [35-37]. To increase their effectiveness, seagrass restoration efforts should improve predictive models combining environmental and genomic data (Figure 1) to have a reliable guideline for helping decision-making in the development of restoration plans [38].

As we are approaching a new decade of ecosystem restoration [39], the need to rebuild marine life for a sustainable future has become more urgent than ever before [8]. Here, we aimed to provide a comprehensive review about genetic issues to be considered to perform a successful re-establishment of populations and for recovering lost ecosystem functions. To this end, we first reviewed conceptual frameworks related to genetic components 
in restoration, with a particular emphasis on seagrasses. We then discussed different genetic-related aspects to be considered for restoring degraded environments, including the choice of whether replicate or reinforce the extant genetic structure, the importance of having genetic diversity and connectivity maps, the selection of donor sites as well as the monitoring efforts after transplantation. We also investigated the actual situation of legal and ethical issues dealing with seagrass restoration at a regional, national and international scale. Finally, we discussed novel approaches and future directions for seagrasses genetic research that could improve the success of restoration activities.

Healthy habitat

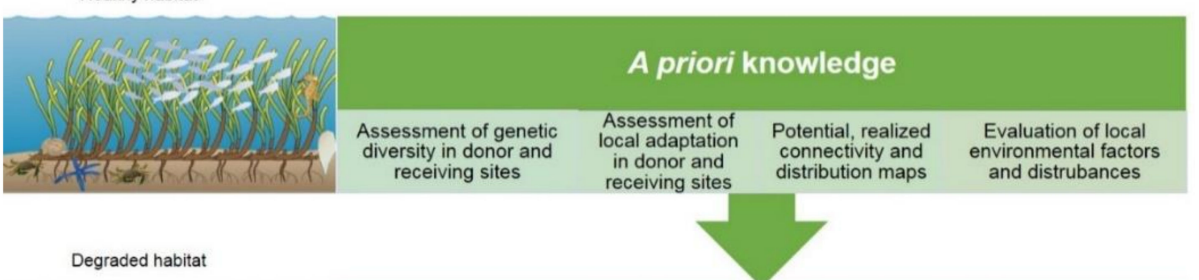

Degraded habitat
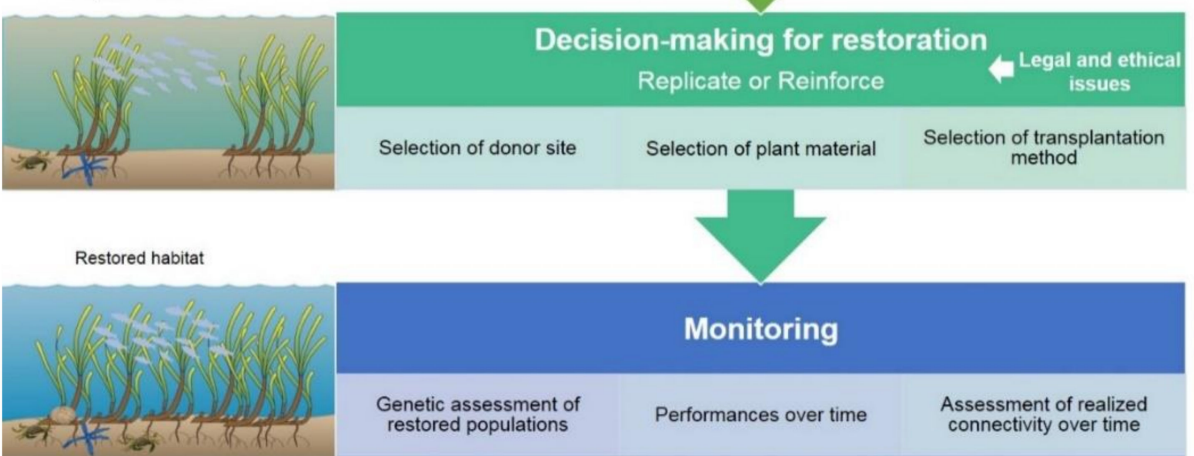

Figure 1. Diagram showing different aspects of seagrass restoration. The restoration plan should include different steps. The "a priori" knowledge includes the assessment of genetic diversity and local adaptation in donor and receiving sites. Moreover, maps of potential and realized connectivity and the evaluation of local environmental status over the whole distribution area of the species are necessary to have a comprehensive baseline to perform a successful restoration plan and to select suitable donor sites. The restoration itself can be aimed to either replicate or reinforce genotypes in target sites and can be performed with different plant material and thorough different restoration methods (always according to the evaluation of legal and ethical issues). In order to assess the restoration success, genetic traits (diversity and connectivity) and performances (physiological, demographic, and growth traits) of newly established meadows must be monitored over time. Symbols were taken from courtesy of the Integration and Application Network, university of Maryland center for environmental science (http: / / ian.umces.edu/symbols/ accessed on 10 March 2021).

\section{A Brief Glance at Factors Shaping Genetic Diversity and Population Structure in Seagrasses}

Genetic diversity is the basis for all biological diversity, which affects evolutionary and ecological processes at population, community, and ecosystem levels. It can be assessed in different ways and encompasses traits such as allelic richness (i.e., the average number of alleles per locus), heterozygosity (i.e., the average proportion of loci that carry two different alleles at a single locus within an individual), or genotypic richness (i.e., the number of genotypes within a population) [40]. Different methods used to quantify genetic diversity are explained in Box 1 . Below, we briefly summarize the main factors shaping genetic variability and differentiation of seagrass populations, which should be taken into consideration for restoration purposes and should be a target for future research efforts.

\subsection{Reproductive Strategies, Mutations}

The level of genetic diversity in seagrass populations results from the balance between their sexual reproduction and clonal propagation, which in turn is related to different 
factors, including environmental conditions, dispersal abilities, and population connectivity [17,41,42]. Most seagrasses are dioecious [43] and therefore are outcrossed, while other species, such as Posidoniaceae and several Zosteraceae, are monoecious $[44,45]$ with highly variable outcrossing rates [46-49]. As a result, seagrass meadows can range from almost monoclonal, with very low genetic and genotypic diversity [21], to extremely diverse [41]. Clonal growth has been recognized as a winner strategy in seagrasses, avoiding the potential accumulation of deleterious mutations and maintaining the most suitable genotype over time [50]. An important source of genetic variation in marine clonal plants is represented by somatic DNA mutations resulting in genetic mosaicism [51]. In clonal plants, genetic mosaics can occur at different levels of the ramet (i.e., the morphological individual [52]) organization, including (1) within the same module; (2) within connected modules; (3) between different modules that belong to the same clone. Recently, it has been demonstrated that the mosaic genetic variation in a large seagrass clone of Zostera marina was greater within than among ramets, pointing out the importance that somatic mutations have in structuring genetically unique modules [53].

\subsection{Level of Genetic Connectivity, Population Size, and Genetic Drift}

For species with a wide distribution range, different factors can contribute to population isolation [54]. Moreover, despite the apparent spatial uniformity of the sea, marine habitats are characterized by clear discontinuities, and the presence of dispersal barriers may create a genetic breakdown in marine populations due to local selective pressures [55]. Nevertheless, dispersal vehicles such as buoyant fruits and vegetative propagules can travel long-distance transported by marine currents (potential connectivity), and new genotypes or allelic variants can establish in disjoint populations (realized connectivity [56-58]). This implies that even if sexual reproduction occurs at a low rate, passive transport of sexual propagules can play an important role in maintaining population connectivity and in the colonization of new habitats [59]. Isolated and small populations are more prone to undergo genetic drift and bottleneck events, increasing allele loss and the possibility of fixation for deleterious alleles compromising their persistence in the future $[49,60]$. This is even more relevant considering the fragmentation of populations resulting from the current destruction of natural habitats [61]. These processes may thus lead to genetic erosion, reducing the fitness of individuals and increasing the chance populations can disappear [62].

\subsection{Phenotypic Plasticity and Local Adaptation}

Different populations of the same species distributed over environmental and geographic gradients can be locally adapted, depending on selection and patterns of gene flow. Local adaptation occurs when individuals have higher average fitness in their local environment compared to individuals from elsewhere [63]. The measurement of adaptive genetic diversity is more difficult than neutral genetic diversity and requires an accurate analysis of genotype-by-environment interactions [20]. Disentangling plasticity from environmentally driven adaptation requires experimental approaches such as reciprocal transplants and common garden experiments $[20,64-66]$ that have been performed in few seagrass species. Experiments carried out on Z. marina and Posidonia oceanica populations from divergent climatic regions highlighted a high divergence in their phenotypes in response to environmental stressors (e.g., heat stress [67-69]). Within populations, variations in acclimation to warming were observed among $P$. oceanica individuals collected along a depth cline [70], while a reciprocal transplant in a common garden [71] of plants coming from different depths (i.e., contrasting light-environment) showed clear indications of local adaptation. Thus, a deep knowledge of eco-physiology of plants at the donor and target sites is also required to perform restoration programs. Although genetic linkage mapping [72] is not applicable for most seagrass species, due to the scarcity of genomic resources, a genetic-environment association analysis, using a genome scan approach and a genome-wide transcriptome analysis, started to identify genetic loci and functions potentially associate with the selective environmental factors along either a latitudinal and 
a bathymetric gradient [73]. Collectively, these studies suggest that local adaptation might play a role in shaping the divergence of seagrasses across environmental clines, even if it is not yet possible to assess how much of the observed phenotypic differences are heritable.

\subsection{Disturbances}

High genotypic diversity has been demonstrated to enhance the resistance and resilience of seagrasses to physical disturbances $[17,74-76]$ or other stressful conditions such as heat stress or shading [76-78]. The level of genetic diversity of seagrass populations has also been shown to correlate with species richness and productivity $[79,80]$ and ultimately with the associated community structure [79]. A high disturbance level can affect genetic diversity, leading to a decline in allelic or genotypic diversity or even to complete population extinction. Intermediate level of disturbance, instead, can boost sexual reproduction, increasing both allelic and genotypic diversity [17]. In general, the relationship between disturbance and genetic diversity is not simple, and the reciprocal causality of the two phenomena renders it difficult to assess the relative contribution of disturbance strength and frequency in relation to its effects on genetic components of diversity [17,40].

\section{Integration of Genetic Research into Seagrass Restoration}

How should a restored meadow be in order for it to successfully perform and persist? It should be genetically diverse and composed of genotypes locally adapted or able to adapt to the local environmental conditions. It should be connected, through a sufficient level of gene flow, with surrounding populations, in order to avoid negative effects of inbreeding depression, but it should not disrupt the local gene pool. It should be established to limit the damage to existing populations in providing source material and should comply with ethical and legal issues. Here we present and comment on key aspects to consider for a correct restoration plan.

\subsection{Selection of Donor Sites}

Genetic diversity is at the base of phenotypic diversity, which determines how restored populations will perform and respond to environmental stimuli at restored sites [74,75,81]. Prior to any restoration project, an accurate understanding of local environmental conditions and potential disturbances, the genetic makeup of populations nearby the transplantation site, and policies and legislation guidelines should be acquired in order to select proper donor sites. Many studies have investigated the relationship between genetic diversity (of both source and transplanted meadows) and the success of seagrass restoration plans (see Table 1). Those studies indicate that the selection of donor sites displaying a high level of genetic diversity as well as the choice of plant materials (e.g., adult plants, seeds, or seedlings) is crucial for maximizing restoration success.

Table 1. List of the most relevant studies investigating the effects of genetic diversity on seagrass restoration plans. Data were collected from Google Scholar using "seagrass restoration" plus "seagrass genetic" as keywords together with personal knowledge from the authors. Year: year when transplantation started; *: multiple restorations; related ref: see related reference for more details.

\begin{tabular}{|c|c|c|c|c|c|c|c|c|}
\hline Species & Year & $\begin{array}{l}\text { Donor } \\
\text { Location }\end{array}$ & $\begin{array}{l}\text { Restored } \\
\text { Location }\end{array}$ & $\begin{array}{c}\text { Plant } \\
\text { Material }\end{array}$ & Area & Duration & $\begin{array}{c}\text { Genetic } \\
\text { Diversity } \\
\text { Assessment }\end{array}$ & Ref. \\
\hline $\begin{array}{l}\text { Posidonia } \\
\text { australis }\end{array}$ & 2013 & $\begin{array}{l}\text { Jervis Bay } \\
\text { (Australia) } \\
\text { reciprocal } \\
\text { transplant } \\
\text { study }\end{array}$ & $\begin{array}{l}\text { St. Georges } \\
\text { Basin } \\
\text { (Australia) } \\
\text { reciprocal } \\
\text { transplant } \\
\text { study }\end{array}$ & $\begin{array}{l}\text { Adult } \\
\text { plants }\end{array}$ & na & 6 months & $\begin{array}{c}\text { Eight } \\
\text { microsatellites }\end{array}$ & [11] \\
\hline $\begin{array}{c}\text { Zostera } \\
\text { noltei }\end{array}$ & 2009 & $\begin{array}{c}\text { Carteau in } \\
\text { the Gulf of } \\
\text { Fos } \\
\text { (France) }\end{array}$ & $\begin{array}{l}\text { Berre lagoon } \\
\text { (France) }\end{array}$ & $\begin{array}{l}\text { Adult } \\
\text { plants }\end{array}$ & $450 \mathrm{~m}^{2}$ & 4 years & $\begin{array}{c}\text { Nine } \\
\text { microsatellites }\end{array}$ & [82] \\
\hline
\end{tabular}


Table 1. Cont.

\begin{tabular}{|c|c|c|c|c|c|c|c|c|}
\hline Species & Year & $\begin{array}{l}\text { Donor } \\
\text { Location }\end{array}$ & $\begin{array}{l}\text { Restored } \\
\text { Location }\end{array}$ & $\begin{array}{c}\text { Plant } \\
\text { Material }\end{array}$ & Area & Duration & $\begin{array}{c}\text { Genetic } \\
\text { Diversity } \\
\text { Assessment }\end{array}$ & Ref. \\
\hline $\begin{array}{l}\text { Zostera } \\
\text { marina }\end{array}$ & 2007 & $\begin{array}{c}\text { Mobjack } \\
\text { Bay, Chesa- } \\
\text { peake Bay, } \\
\text { South Bay, } \\
\text { USA }\end{array}$ & $\begin{array}{l}\text { Hog Island Bay, } \\
\text { USA }\end{array}$ & Seeds & $128 \mathrm{~m}^{2}$ & 20 months & $\begin{array}{c}\text { Eight } \\
\text { microsatellites }\end{array}$ & [83] \\
\hline $\begin{array}{l}\text { Zostera } \\
\text { marina }\end{array}$ & $2006-2007^{*}$ & $\begin{array}{l}\text { Chesapeake } \\
\text { Bay (USA) }\end{array}$ & $\begin{array}{l}\text { Virginia coastal } \\
\text { bays (USA) }\end{array}$ & Seeds & na & $2-3$ years & $\begin{array}{c}\text { Eight } \\
\text { microsatellites }\end{array}$ & [84] \\
\hline $\begin{array}{l}\text { Posidonia } \\
\text { australis }\end{array}$ & 2004 & $\begin{array}{l}\text { Parmelia } \\
\text { Bank, } \\
\text { Cockburn } \\
\text { Sound } \\
\text { (Australia) } \\
\end{array}$ & $\begin{array}{l}\text { Southern Flats, } \\
\text { Cockburn } \\
\text { Sound } \\
\text { (Australia) }\end{array}$ & $\begin{array}{l}\text { Adult } \\
\text { plants }\end{array}$ & 3.2 ha & 4 years & $\begin{array}{c}\text { Seven } \\
\text { microsatellites }\end{array}$ & [85] \\
\hline $\begin{array}{l}\text { Zostera } \\
\text { marina }\end{array}$ & $2001-2008$ * & Related ref & related ref & $\begin{array}{l}\text { Adult } \\
\text { plants }\end{array}$ & $\begin{array}{l}\text { related } \\
\text { ref }\end{array}$ & 10 years & $\begin{array}{c}\text { Seven } \\
\text { microsatellites }\end{array}$ & [86] \\
\hline $\begin{array}{l}\text { Zostera } \\
\text { marina }\end{array}$ & 2000 & $\begin{array}{l}\text { Two sites } \\
\text { along the } \\
\text { German } \\
\text { Baltic Coast }\end{array}$ & $\begin{array}{l}\text { Two sites along } \\
\text { the German } \\
\text { Baltic Coast }\end{array}$ & $\begin{array}{l}\text { Adult } \\
\text { plants }\end{array}$ & $450 \mathrm{~m}^{2}$ & 11 weeks & $\begin{array}{c}\text { Four } \\
\text { microsatellites }\end{array}$ & [87] \\
\hline $\begin{array}{l}\text { Zostera } \\
\text { marina }\end{array}$ & Late 1990s & $\begin{array}{l}\text { Chesapeake } \\
\text { Bay }\end{array}$ & $\begin{array}{l}\text { Twenty-three } \\
\text { meadows } \\
\text { along the } \\
\text { eastern coast of } \\
\text { North America }\end{array}$ & Seeds & 1600 ha & 15 years & $\begin{array}{c}\text { Seven } \\
\text { microsatellites }\end{array}$ & [88] \\
\hline $\begin{array}{l}\text { Posidonia } \\
\text { oceanica }\end{array}$ & 1994 & $\begin{array}{l}\text { Gorgona } \\
\text { Island, } \\
\text { Pantelleria } \\
\text { Island } \\
\text { (Italy) }\end{array}$ & Vada (Italy) & $\begin{array}{l}\text { Adult } \\
\text { plants }\end{array}$ & na & 3 years & $\begin{array}{l}\text { Six } \\
\text { microsatellites }\end{array}$ & [89] \\
\hline $\begin{array}{l}\text { Halodule } \\
\text { wrightii }\end{array}$ & $1993-2000$ * & Related ref & Related ref & $\begin{array}{l}\text { Adult } \\
\text { plants }\end{array}$ & na & $2-7$ years & 98 AFLPs & [90] \\
\hline $\begin{array}{l}\text { Zostera } \\
\text { marina }\end{array}$ & 1993 & $\begin{array}{l}\text { South San } \\
\text { Diego Bay } \\
\text { (USA) }\end{array}$ & $\begin{array}{l}\text { North San } \\
\text { Diego Bay } \\
\text { (USA) }\end{array}$ & $\begin{array}{l}\text { Adult } \\
\text { plants }\end{array}$ & na & 2 years & $\begin{array}{c}\text { Allozyme } \\
\text { electrophoresis }\end{array}$ & [81] \\
\hline $\begin{array}{l}\text { Zostera } \\
\text { marina }\end{array}$ & related ref * & Related ref & Related ref & $\begin{array}{l}\text { Adult } \\
\text { plants }\end{array}$ & $\begin{array}{c}\text { Related } \\
\text { ref }\end{array}$ & $3-16$ years & $\begin{array}{c}\text { Allozyme } \\
\text { electrophoresis }\end{array}$ & [91] \\
\hline
\end{tabular}

To date, the most widely applied approach of restoring a former local gene pool is by sourcing the plant material from nearby or well-connected donor sites, i.e., local provenance (Figure 2). The reason is that locally adapted plants are believed to fit the condition of the site being restored. However, trying to replicate what is already lost is inappropriate in highly degraded environments, and better environmental conditions should be achieved first.

Native genotypes that have already suffered past environmental disturbances could also be unable to overcome the recurrence of such perturbation or new stressful conditions in the future [36]. Sgrò et al. [92] identified critical problems of this "local is best" practice, including (1) the risk of establishing populations that do not exhibit sufficient genetic variation and evolutionary potential; (2) the possibility that particular environmental conditions driving local adaptation can change very quickly, hampering the advantage of using locally adapted genotypes. This is particularly important and can cause serious impacts on restoration outcomes, considering the speed at which environmental changes are occurring. On the other hand, the introduction of novel genotypes from distant sources (assisted gene flow) has the potential to restore levels of genetic diversity (genetic restoration), increasing the overall fitness of inbreeding-depressed populations (genetic rescue). Nevertheless, it may also result in deleterious effects as a consequence of outbreeding depression and maladaptation [93,94]. According to a modeling approach by Aitken and Whitlock [95], 
the risks and consequences of outbreeding depression and contamination of the local gene pool are minor in respect to potential advantages.

Another important aspect to consider in the selection of donor sites is the taxonomic uncertainty, which characterizes some seagrass groups, such as, for example, the Halophila genus $[96,97]$. The high morphological plasticity of species and the presence of locally adapted morphotypes could lead to erroneous species identification. This could favor in turn, the hybridization with native species, the breakdown of locally adapted ecotypes, and the establishment of hybrids (i.e., genetic swamping), potentially compromising the entire ecosystem functioning [98]. In this case, species identification should also be performed at a genetic level to overcome taxonomic ambiguity.

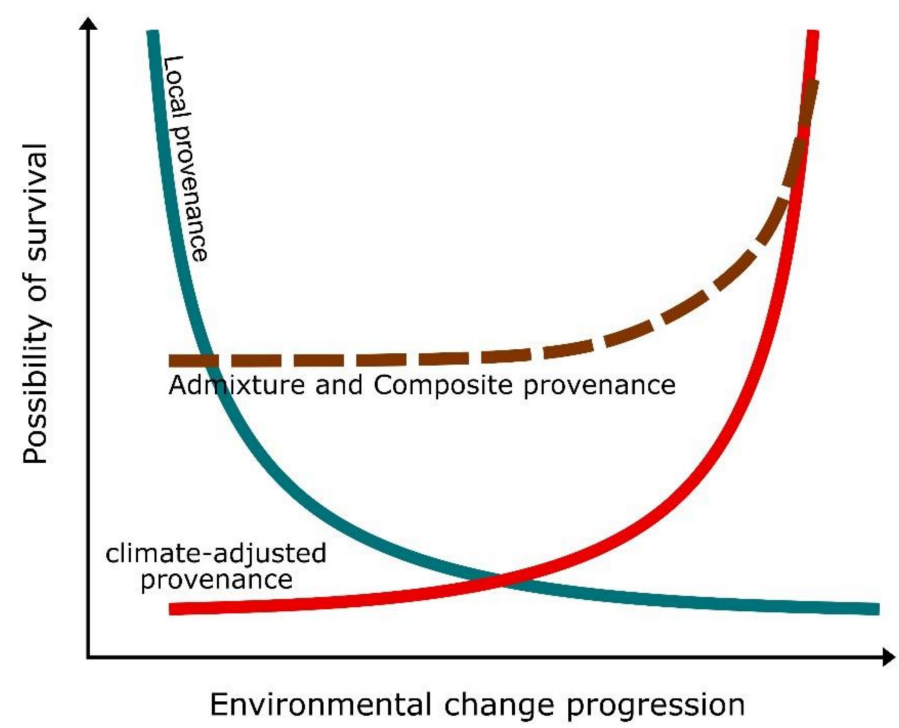

Figure 2. Graph showing the conceptual relationship between local (blue line), climate-adjusted (red line), admixture and composite (dashed line) provenance (sensu Prober et al. [99]) with the possibility of survival of the restored seagrasses under environmental change (e.g., ocean warming, eutrophication, etc.).

In order to utilize donor material potentially able to respond to projected climate changes, source populations can be selected within the distribution range of the species in areas experiencing environmental conditions as projected in the near future for the transplantation site, i.e., climate-adjusted provenance (Figure 2, red line) [88]. This source material could be utilized together with material coming from healthy local populations or from multiple sources across the species range, i.e., a composite and admixture provenance (Figure 2, dashed line) [99]. The latter is especially suitable for most seagrass species, where information about genotypic plasticity and potential response to changes is scarce. Furthermore, many seagrass species exhibit wide latitudinal ranges of distribution [100], making the selection of climate-adjusted or admixture provenance easier. These strategies may not result in a high survival rate of restored populations in the short-term as they can experience intraspecific hybridization with local and non-local genotypes (i.e., outbreeding depression) or maladaptation $[93,94,101]$. However, in the long-term, the introduction of "future climate-adapted" genotypes can enhance the survival and longevity of the restored meadows $[6,10,99]$. Even holding great potentials for seagrass restoration, there are still limitations in choosing non-local donor material approaches that require further investigation. For instance, to apply admixture provenance, it is important to establish the right proportion of local and climate-adjusted plant material and the number of donor populations to select. Sometimes, this is also highly dependent on the availability of material at both source and receiving sites (see Section 3.2). 


\subsection{Integration of Biogeographic and Genetic Data}

Integrating genetic diversity information with biogeographical and oceanographic data into connectivity maps can be very helpful in the selection of donor sites and the monitoring of restoration efforts (Figure 3). This becomes particularly useful for species with the potential to disperse over long distances via ocean currents during various life stages $[59,102]$ and for species with a highly variable level of meadow genetic diversity over their distribution range (e.g., P. oceanica $[103,104])$. These maps, together with habitat suitability and site selection models [105], are important to identify whether or not seagrass recovery can naturally occur or whether the targeted population would remain isolated after being restored (in this case, restoration is not advisable). In the first case, it is the result of a high level of connectivity and gene flow between degraded and neighboring sites, or in the second case, resulting from the absence of population connectivity. In the last case, the integration of genetic diversity, connectivity, and environmental data could reveal the reasons behind the isolation of the target area and the possible way of restoring dispersal and connectivity networks ([106]). Recently, Mari and colleagues [58] built maps of potential connectivity for $P$. oceanica, modeling the dispersal and potential exchange of propagules between sites evaluating environmental features. The resulting patterns could be integrated with genetic data of target populations useful for choosing potential donor populations. Survival data from seagrass restoration can also be used to investigate fundamental niches and model the persistence potential of restored seagrass meadows [107,108]. Recently, Oreska et al. [109] analyzed the presence and absence data of seedlings from restored plots in the Virginia Coast Reserve through Species Distribution Models (SDMs) to identify potential environmental factors that affect the survival rate of different sites. This offered the opportunity to compare the extent of the realized and fundamental niche of the restored and natural sites, improving management efforts to accelerate seagrass coverage and recovery.

The integration of information from genetic diversity into connectivity maps may also help to keep track of historical gene flow and local adaptation while at the same time, avoid the loss of genetic variation at the restored sites [110]. Seagrass genetic diversity tends to decrease in populations that locate at the range-edge of the species' distribution range [49,102]. This phenomenon has been suggested as the result of reduced seed production and pollen limitation [10,49] and limited connectivity of populations [111-113]. Range-edge populations often exhibit smaller effective population sizes, making them unsuited as donor sites [111,112,114]. Indeed, many studies have recommended that populations with large effective population sizes are the most appropriate donor sites [114]. These populations actually possess the genetic potential to better adapt to more extreme environmental conditions (e.g., marine heatwaves) and could be used as potential restoration materials for the future as ocean warming continues to rise $[10,111]$. However, these populations could also be at high risk of extinction if the speed of environmental change overrides their capacity to adapt [115].

Distribution and connectivity maps together with a priori knowledge of population structure should be integrated with the reproductive characteristics of related seagrass meadows $[111,116]$. For example, after studying reproductive and genetic profiles of $P$. australis meadows across Western Australia, Sinclair et al. [111] showed flower and fruit production variability between northern range-edge meadows and center range ones, with the first showing mixed mating system and lower sexual productivity. This evidence suggests that future restoration activities may benefit from sourcing plant material from multiple reproductive meadows. Future efforts on making complete maps (or georeferenced databases) as guidelines to restoration should also include information regarding intraspecific differences in genetic diversity, e.g., among different depths of the same population as seen in the case of the seagrass Z. marina [115] and P. oceanica [117,118], which can have potential implications in the collection of plant material. 


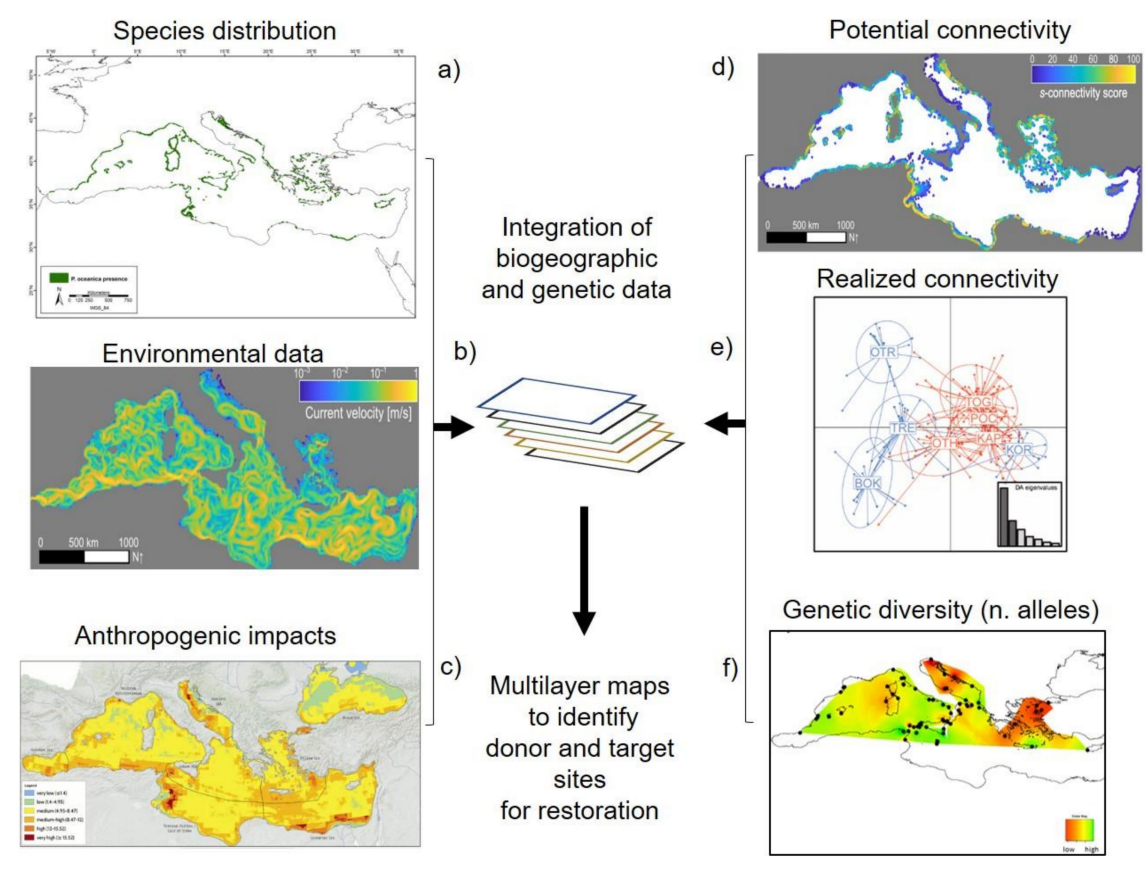

Figure 3. Examples of models and distributions maps and genetic data from seagrass' studies of the Mediterranean Sea. The integration of species distribution (a [119]), environmental data (b [58]), anthropogenic impacts (c [120]), with potential (d [58]) and realized connectivity maps (e [57]) and genetic diversity analysis (f [121]) could be combined to develop multilayers maps for the identifications of donor and target sites in seagrass restoration (see text for more detail). The figure was modified from the studies cited above.

\subsection{Selection of the Plant Material}

Different species of seagrasses have different morphological and reproductive traits, affecting in a different way restoration success. Moreover, restoration plans have mainly focused on species with higher ecosystem value (providing more valuable ecosystem services) and also forming monospecific meadows. Only one-third of the extant seagrass species have been utilized in restoration programs, with Z. marina present in more than $50 \%$ of the trials [122]. Other species highly utilized in restoration plans are the ones from the Posidonia genus in the Mediterranean and in Australia. Most of the restoration plans occur in temperate areas of the United States, Europe, Australia, and Eastern Asia [122].

Seagrass restoration can be performed by using different parts of the plant, such as rhizome fragments, seedlings, or seeds [122]. The most common approach implies the collection of adult plants with well-developed shoots and roots [85,122]. However, adult plant-based methods are often labor-intensive and costly, as the survival rate of transplanted shoots is strongly related to the amount of planted material used [10]. In contrast, the use of seed-based methods instead of adult shoots, particularly in large restoration plans, can result in a much lower impact on existing meadows (i.e., donor sites) [10]. Moreover, seed-based transplantation approaches are less expensive and more logistically feasible when restoring larger areas [88,123]. As reported by van Katwijk et al. [122], large-scale restoration trials (> 100,000 shoots/seeds planted) perform better than small trials, and part of these results depend on the initial sourcing material, which should have high genetic and genotypic diversity. One of the best examples of large-scale restoration in seagrasses was performed along the mid-western Atlantic coast, where over 70 million Z. marina seeds were planted from 1999 to 2010 [124]. In this case, the collection of a large number of seeds from multiple parents did offset potential genetic bottlenecks ensuring high genetic diversity of donor plants and thus of restored sites [84]. Orth et al. [125] also demonstrated that a large restoration plan not only restored local seagrass coverage but also improved water quality and ecosystem functioning, supporting other restoration programs (e.g., scallops). Seed-based methods can quickly facilitate the recovery of populations with 
higher genetic diversity $[83,90]$ and have the advantage of maintaining genetic variation mimicking natural ecological and evolutionary processes [92,123]. Thus, it is considered as a valid approach to restore and redefine populations that are more capable of persisting to changing environmental conditions. However, it is still unclear if and how massive seed collection can impact the survival and genetic composition of donor populations in the long-term. Although the acquisition and processing of large amounts of seeds is a limiting factor in most seagrass species, other species, such as Z. marina, produce large quantities of seeds that are released in a short time, allowing the implementation of different approaches to store and maintain collected seeds viable [126].

Nevertheless, seed-based methods still have limitations that deserve further efforts from the scientific community. For example, more information is needed about sexual reproduction and other biological characteristics of plants, such as flowering time, seed production strategies, dormancy, and germination condition. Furthermore, it has been found that in P. australis new seedlings have a low initial establishment rate, which depends on local environmental conditions [127], while in Z. marina in natural conditions, only around $5 \%-10 \%$ of seeds can survive and germinate [128].

\subsection{Genetic Assessment of Transplantation Success}

The success of seagrass restoration has historically been evaluated by demographic monitoring, which only informs about population processes such as recruitment, survival, and reproductive success, but that do not provide insights into the evolutionary resilience of restored populations or about the consequences of reproductive processes following restoration actions [129]. Genetic monitoring evaluates the success in restoring genetically viable populations and whether the positive effects of the restoration are maintained over time (i.e., across successive generations). Thus, well-designed monitoring programs are required, including also evaluation of changes in environmental conditions of the restored site and referring to comparable time frames for the same species [130]. Monitoring genetic changes in restored populations can be done retrospectively by using pre-disturbance genetic population datasets or for evaluating ongoing changes in their status and persistence (i.e., mid-and long-term restoration outcomes). Measuring changes in population allele frequencies or levels of linkage disequilibrium over time, using neutral markers, can provide information about absolute changes in the restored population (e.g., effective population size) and can be relevant for digging into the genetic processes driving these changes (e.g., selection, genetic recombination, mutation, genetic drift, mating system, and genetic linkage).

Genetic monitoring can also be useful to inform about the factors and processes underlying the success or failure of a restoration action, which could be critical to adjust management practices accordingly [131]. For instance, when mixed source populations are used in restoration, genetic monitoring has the potential to inform whether genotypes from different origins have been admixed or if the local genetic characteristics are maintained and not completely replaced by the newly introduced foreign genotypes. In the latter case, this would involve a reduction in the overall genetic diversity of the restored population, compromising its evolutionary potential in future environmental scenarios. In species with high clonal propagation, genetic monitoring could also inform whether the establishment of new recruits is the result of clonal spread or sexual reproduction, the latter being indicative of successful population rejuvenation [132].

Combining molecular markers with fitness-related phenotypic traits can provide a quantification of genetic variability and structure, as well as further valuable information about the progression of the restored population and the likely existence of constraints to recovery. For instance, genetic monitoring just several generations after the completion of a restoration action can reveal the existence of reduced fitness of inbred offspring (inbreeding depression; Z. marina [68]) or reduced fitness of progeny involving an admixture of different sources or of native and foreign genotypes (outbreeding depression; Z. noltei [133]). Additionally, monitoring the genetic structure of restored populations can identify the 
re-establishment of a gene flow between the restored and closely populations (e.g., $Z$. muelleri [134]) as well as factors that have the potential to alter the future population genetic structure (e.g., Z. marina [135]). Whether selection pressures in the restored habitat with mixed source populations have the potential to result in population differentiation in the long term can also be inferred. Since fitness of transplants may depend both on the source origin and the particular environmental conditions of the restored habitat, the higher fitness in critical traits (e.g., sexual reproduction) of locally adapted genotypes might result in within-population differentiation. This can also result from heterosis, as heterozygous individuals are relatively fitter than homozygous individuals [136].

In addition, genetic monitoring could also shed light on the genetic basis influencing the provision of ecosystem services [133], which is a major outcome pursued in restoration programs. Reynolds et al. [84] found that a small increase in genetic diversity in transplant plots of the seagrass Z. marina improved restoration success, but also the provision of valuable ecosystem services (i.e., habitat provision, primary productivity, and nutrient cycling). The authors argued that the mechanism behind this ecosystem services enhancement was the increase in shoot density promoted by high genetic diversity in transplant plots.

For all the above, monitoring of transplants is essential to identify timely evidencebased information that can ultimately enhance the long-term success rates of transplantation efforts by establishing additional actions and modifications (see Figure 1). This information can also uncover mechanisms limiting transplantation success to inform future projects [124]. As the recovery of seagrass meadows can take from two to over 30 years to reach a fully functional state [6], and negative impacts of improper donor sites (e.g., in genetic aspects) can also take decadal times to be detectable [101,137]. All these make longterm seagrass monitoring essential. Unfortunately, most agencies typically fund restoration projects over a short period (e.g., in Australia from one to 10 years [6]) that is usually not enough for appropriate monitoring. Besides the devoted efforts of the scientific community, restoration programs require the involvement and commitment of all stakeholders in the industry, local communities, citizen-science projects, non-governmental organizations, states, and federal government agencies to establish multi-year to decadal funded restoration projects in order to progressively improve seagrass restoration outcomes and to complete the ambitious restoration goals set out for the present decade.

\section{Future Directions in Seagrass Restoration}

\subsection{Improving Transplant Performances through Assisted Evolution}

The ability for impacted or vulnerable seagrass populations to successfully adapt to environmental changes depends on their standing genetic variation and the pace at which genetic changes are incorporated [138]. However, in the context of accelerated climate change, the genetic adaptation of populations is considered slow compared to the celerity of climatic changes [139]. Different approaches with diverse levels of intervention intensity have been proposed within the concept of "assisted evolution" (or assisted adaptation) to accelerate the rate of naturally occurring evolutionary processes (e.g., corals [140], terrestrial plants [141]). Although such human interventions are under strong ethical debate (as discussed in Section 5), it is timely to start exploring and discussing the potential possibilities we have to secure a sustainable future for seagrasses.

The use of resistant genotypes in seagrass restoration is an approach with the potential for improving the extant genetic baselines of natural populations and for enhancing the resilience of the restored population to present and future stressors. Resistant genotypes can be identified through manipulative selection experiments and by identifying local adaptation (i.e., selection) in natural populations. Genotyping by sequencing of single nucleotide polymorphisms (SNPs) now enables to explore genome-environment interactions and to characterize both neutral and functional (adaptive) genetic diversity of organisms without a reference genome (see Box 1), which is the case of most seagrass species. The identification of putative heritable loci under selection for a given stressor (e.g., thermal stress) could then be combined with manipulative stress experiments to confirm candidate 
gene function and to examine the resilience and the potential trade-off of genotypes possessing such loci [142]. This information could be crucial for improving seagrass restoration outcomes by facilitating an informed decision-making process about the provenance and genetic background of the transplant material. Furthermore, this can also be relevant in the future thanks to the recent development of novel technologies in genome editing, which are opening up new opportunities for molecular ecologists to achieve specific manipulation of genes of interest for improving restoration outcomes and for enhancing the overall resilience of restored populations $[143,144]$. However, these approaches require a high level of human intervention that are more socially and ethically controversial and still far from being applied in seagrasses, although they are common in terrestrial plants and animals and have been proposed in certain cases of coral reef restoration [35,140]. However, legal guidance on how to define organisms produced by exploring novel genome editing techniques and how to distinguish them from genetically modified organisms (GMOs) is still under construction [145].

The selection of more tolerant genotypes to improve restoration success can be performed by growing wild specimens under controlled conditions. These practices that include a culture phase are widely applied for coral restoration, where fragments or larvae are collected from the environment in order to prevent coral damage during their most vulnerable stages [7]. In seagrasses, the use of aquaculture systems to grow plants of $Z$. marina has been improved and representsd a way to obtain plant material alternative to harvesting plants from donor sites when vegetative shoots are required [146]. Additionally, growing plants under controlled conditions is useful to overcome acclimation to the home environment, avoiding problems related to the choice of a local or non-local site [20]. Although this approach can also be applied to other seagrass species, several constraints regarding reproductive cycles of the species, germination of seeds under control conditions, and slow growth rate limit its application.

Resistant genotypes can also be produced with a lower level of intervention through the use of priming/hardening methods [147]. Pre-exposing individuals to mild stress have the potential to induce stress memory, giving rise to genotypes with enhanced tolerance to subsequent stressful events. Whether stress memory is set by stress-induced epigenetic modifications (see Section 4.2), the acquired resistance can be passed to offspring leading to new generations with acquired resistance [148]. The first evidence of the existence of stress memory in seagrasses has very recently been published [149]. Adults of two seagrass species with contrasting biological attributes (pioneer vs. climax) have shown the capacity to acquire thermal-stress memory and to better resist and perform in a successive stressful thermal event. Primed plants also showed the activation of methylation-related genes suggesting the involvement of epigenetic modifications on stress memory in seagrasses, as also suggested in a recent paper on Z. marina [150].

\subsection{Potential of Epigenetics in Seagrass Restoration}

Plasticity provides a buffer against rapid climate changes and also assists the rapid adaptation of species and populations to the ongoing climatic change [20,139]. Among mechanisms promoting and regulating phenotypic plasticity, epigenetic modifications, which include potentially heritable changes of genomes that do not alter the DNA sequence itself, have been widely considered as key candidates [151,152]. Epigenetic variations can arise from genetic control, environmental induction, or spontaneous epimutations [151,153]. Epigenetically induced phenotypic variations could be transiently reversible or transgenerationally heritable within one or multiple generations through meiosis and/or mitosis [154]. Especially clonal plants such as seagrasses could benefit from epigenetic variations and their adaptive potential as an alternative to the slower mechanisms of adaptation through natural selection $[155,156]$. In addition, under clonal growth, epigenetic changes (e.g., DNA methylation patterns) are expected to be more stably inherited than under sexual reproduction [157]. 
In seagrasses, different studies pointed out the potential role of epigenetic mechanisms in regulating gene expression following stress events, thus promoting stress acclimation and increasing tolerance of individuals $[19,24,70,158-160]$. A very recent study in the seagrass Z. marina tested the hypothesis that clonal seagrass meadows could display epigenetic variation that compensates for low genetic variation [150]. Clonal shoots displayed DNA methylation variations independent from underlying genetic variations and associated with changes in plant performance under experimental conditions [150]. This demonstrates that epigenetic variation could play a similar role to genetic diversity in meadows dominated by a single or a few genotypes and that seagrass stress resilience could be much higher than expected considering only the genetic makeup of populations. Especially in long-living seagrass species (e.g., P. oceanica [21]), epigenetic responses can build through time, thus increasing the fitness of individuals over a number of ramet generations [155].

Consequently, when dealing with clonal plants, conservation and restoration management should consider 'epigenetic diversity' as an indicator of stability and functioning of the ecosystem equal to genetic diversity [161,162]. In a framework of restoration, the assessment of the epigenetic variation of populations could be potentially as informative as the assessment of their genetic status, thus being a reliable tool for the evaluation of suitable donor sites as well as for establishing the success of replanted shoots to overcome natural variability and stress events. As recently stated by Rey et al. [163], DNA-methylation, which is the most studied epigenetic modification, could contribute to improving ecological restoration, including the development of biomarkers, the study of wild populations' ecological structure, the improvement of translocation strategies, and the study of functional landscape connectivity. Introducing epigenetics into conservation and restoration practices, especially in seagrasses, would contribute to better understanding the plasticity of these unique plants and their adaptive potential in the face of environmental changes, thus improving conservation and restoration strategies [163].

\section{Legal and Ethical Issues Related to Genetic Aspects of Seagrass Restoration}

Conservation and restoration programs are generally regulated by national laws and international conventions with a central role of maintaining biological diversity [164,165]. Biodiversity conservation is regulated in the framework of the Convention on biological diversity (CBD) that was signed by 150 government leaders in Rio de Janeiro in 1992. The CBD aimed to stem the worldwide biodiversity loss, focusing on the conservation of biodiversity, sustainable use of the components of biological diversity, and sharing benefits derived from genetic resources. Importantly, an explicit goal of the CBD was the conservation of genetic diversity, as the persistence and evolutionary potential of species depend on it [166]. Other conventions with a role in seagrass conservation and management are the Berna Convention (1979), which deal with the conservation of wild species and European natural habitats, the Barcelona Convention (1995), which was recognized as the convention for the protection of marine habitats, and a series of other legislations related to fisheries and aquaculture [167]. In addition, the inclusion of seagrass ecosystems in national and international policies is a recommended action for the maintenance of marine ecosystems and biodiversity (UNEP, UN Environment Program 2020). The UN decade on ecosystem restoration [168] is an international call that aims to massively restore degraded ecosystems worldwide during the period 2021-2030, as well as to promote their resilience to climate and anthropogenic changes. The UNEP offers regional and international collaborations in broad thematic areas, including the protection and restoration of coastal 'blue carbon' ecosystems, like mangroves and seagrasses.

However, no specific regulations and practical implementations exist on the management of the genetic component in seagrass restoration practices. One exception is Article 15 of the Convention on biological diversity (CBD), where terms and conditions for access to genetic resources were recognized, such as the sovereignty of States over their natural environments (see Secretariat of the Convention on Biological Diversity 2002 [169]). The introduction of some countries' specific restrictions on access to genetic resources could 
limit the possibility of choosing donor sites. One recent addition to the protocols of the CBD was the implementation of the Nagoya Protocol on Access to Genetic Resources and the Fair and Equitable Sharing of Benefits Arising from their Utilization that was adopted on 29 October 2010 [170]. This new protocol introduced legal transparency for both providers and users of genetic resources by sharing benefits arising from the utilization of genetic resources contributing to the conservation and sustainable use of biodiversity as stated by the CBD.

Important management measures on genetic issues related to conservation have been applied for agrobiodiversity, especially for crop species of economic and commercial interest $[171,172]$. In this regard, different regulations and specific institutions already exist, which aim to conserve plants' genetic resources [173]. In 1971, Food and Agriculture Organization (FAO), with the World Bank and the UN Development Program, founded the Consultative Group on International Agricultural Research (CGIAR). Today, the CGIAR is primarily responsible for the international germplasm collections and includes governments, private foundations, and regional development banks (http:/ / www.cgiar.org accessed on 10 October 2020). The conservation of plant genetic resources consists of the storage of crop genetic materials, usually as seeds or vegetative material. This approach, known as ex situ conservation and widely applied for terrestrial plants, consists of the collection of seeds and their storage for future use of plants [174]. The possibility to preserve seeds in seedbanks is strongly species-dependent and population-specific [175] and has not been considered to date for seagrasses. Different guidelines have been developed to improve translocation of plants (i.e., reintroduction) and breeding in restoration [176]. In the presence of highly degraded habitats, where the native species are almost disappearing, a strict sampling strategy must be followed considering the number of populations and individuals within populations to create a sufficient initial gene pool [177]. These guidelines can also be applied to seagrasses, even if more studies performing transplant experiments and addressing genetic diversity effects over the years are needed. Uncertainty related to the management of genetic issues in restoration is exacerbated by ethical questions that arise from novel approaches, such as assisted evolution and genome manipulation [36,178]. The artificial selection of more suitable genotypes or the release of genetically modified genotypes into wild populations opens a debate on the potential consequences that modified genomes can have on native populations. Furthermore, improving populations' performances to human-modified environmental conditions make it harder to define clear interventions' rules. In this context, the lack of long-term outcomes derived from these manipulations raises concerns about the appropriate use of assisted approaches. A constant dialogue among scientists, stakeholders, and policymakers is fundamental to identify opportunities from new technologies and potential risks for the environment.

\section{Recommendations and Conclusions}

In this review, we provide a comprehensive view of the importance of genetic knowledge to seagrass restoration. Whether a restoration program aims to replicate or to reinforce target populations, a proper restoration plan would require: (1) information about the genetic structure of both donor and restored meadows; (2) the analysis of local environmental conditions and disturbances that affect the site to be restored; (3) the analysis of local adaptation constraints influencing performances of donor and native plants; (4) the integration of distribution and connectivity maps with genetic information and environmental factors relative to the target seagrass populations; (5) long-term monitoring programs to assess the performance and the variability of the restored populations over time. In addition, we encourage the inclusion of an 'epigenetic conservation and restoration' perspective together with a genetic one. Further studies in the field of epigenetics in seagrasses are needed to broaden our knowledge on this emerging topic that can ultimately benefit future restoration and conservation activities. These kinds of studies are also crucial for the integration of assisted evolution strategies into seagrass restoration, which needs to be further reasoned and developed in a similar way to what has been done for other marine foundation species 
such as corals $[35,140]$ and kelps [36]. It is urgent and imperative to integrate and develop the concepts and methods of assisted evolution in seagrass restoration to reinforce seagrass ecosystems, avoiding rapid deterioration and promoting their adaptation to local and global pressures.

Bringing solid scientific knowledge from biologists to policymakers is essential to define clear restoration actions, delineating priority areas to restore, and making adequate funds available. Altogether, we expect to ensure a sustainable future for seagrasses and the multiple life forms they support worldwide to our future generations.

Box 1. Current molecular methods to assess seagrass genetic/epigenetic diversity, adaptation, and population structure.

Different molecular methods have been developed to quantify genetic diversity and structure within and among plant populations (see review by [179]). Early studies in seagrasses have largely relied on traditional molecular markers (e.g., Random Amplified Polymorphism DNA, Amplified Fragment Length Polymorphisms, and Restriction Fragment Length Polymorphisms). Some of these marker categories have limited power in assessing population genetics indices and in resolving the geographical differentiation of populations and a limited consistency among studies. Simple Sequence Repeats (or microsatellites) represented the reference markers in population genetics for many years and are still widely utilized, considering that whole-genome sequencing techniques are still too expensive, especially when dealing with tens or hundreds of samples and species with large-sized genomes.

The rapid progress in next-generation sequencing technologies (NGS) speeded up the development of various reduced-representation genome-sequencing (RRS) methods based on restriction enzyme digestion of genomic DNA (for a review see [180]), and genotyping-by-sequencing (GBS) is currently increasingly applied to ecological and evolutionary studies [181]. GBS methods can produce thousands to millions of single nucleotide polymorphisms $\left(\mathrm{SNP}_{\mathrm{S}}\right)$, which allow resolving patterns of genetic diversity, genotyping, and spatial structure of populations at a very fine scale [180].

Restriction-site-associated DNA sequencing (RAD-Seq) is a family of techniques in which DNA is digested with restriction enzymes, and the resulting fragments are size-selected and sequenced via NGS. The resulting NGS reads are mined across individuals for SNPs that occur immediately adjacent to common restriction sites [182]. RAD-Seq provides high-resolution population genomic data for outliers scan, linkage mapping, and demographic analysis at relatively low cost and requires minimal starting material [183]. Diverse RAD-Seq techniques e.g., RAD based on fragments produced by type IIB restriction endonucleases (2b-RAD [184]), Isolength restriction site-associated DNA (isoRAD [185]), or Double digest RADseq (ddRAD [186]), have been developed in recent years (for a review see [187]). Importantly, they can be easily applied to non-model species without prior genomic knowledge [183], as most seagrass species (with the only exception of Zostera marina and Z. mulleri, whose genomes have been recently released [188,189]). A RAD-Seq approach has been recently applied in Zostera capensis to obtain SNPs data and examine the neutral genomic variation of populations [190,191].

NGS platforms can also be used to study genome-wide DNA methylation patterns across the genome to improve the assessment of epigenetic diversity in ecological settings and provide functional insights [192]. Bisulfite sequencing applied to whole genomes (WGBS) allows the evaluation of methylation status for every cytosine in a genome [193], and it represents the 'gold standard' of all available techniques, but it is only applicable to species with a high-quality reference genome, besides having prohibitive costs for large experimental designs. Several cost-effective reduced representation bisulfite-sequencing approaches (RRBS) have been recently developed, as for instance, Methylation-dependent restriction-site associated DNA sequencing (MethylRAD [194]), epi-genotyping by sequencing (EpiGBS [195]) or bisulfite-converted restriction site associated DNA sequencing (BsRADseq [196]) that can be applied to non-model organisms lacking a wellannotated reference genome. The Methyl-RAD technique has been recently applied to characterize the methylome of the seagrass Z. marina [150].

The integration of the various "omics" or "high-throughput" technologies now allows to achieve a comprehensive understanding of the link between genotype, phenotype, and the environment through the application of system biology approaches (for a complete review of new technologies in restoration and conservation, see reviews by [197] and [198]). Moreover, many commercial services are currently available to perform most of the 'genetic work', from library preparation to sequencing and bioinformatics analysis, allowing research in restoration and conservation genetics without access to a fully equipped molecular laboratory. 
Author Contributions: The paper was conceptualized by G.P.; J.P. and H.M.N. lead the bibliographic search, synthesis of information, and draft writing, G.P. and L.M.-G. lead the paper writing; M.R., A.S.-S. and E.D. equally contributed during the whole writing process. All authors have read and agreed to the published version of the manuscript.

Funding: JP was supported by the University of Trieste Ph.D. fellowship shared with SZN. HMN was supported by an SZN Ph.D. fellowship via the Open University. The work was partially supported by the project Marine Hazard (Ministero dell'Istruzione, dell'Università e della Ricerca, Italy, grant/award number: PON03PE_00203_1) and by the project Sea-Stress, Israeli-Italian Scientific and Technological Cooperation, Ministero degli Affari Esteri e della Cooperazione Internazionale (MAECI), Italy.

Conflicts of Interest: The authors declare no conflict of interest.

\section{Glossary}

Admixture provenance: Plant materials for restoration collected as a mixture of Local provenance and Climate-adjusted provenance (i.e., from a variety of provenances from sources across a species range).

Assisted evolution: Conservation strategy adopted for vulnerable species and based on human intervention, which aims to accelerate the rate of natural evolutionary processes enhancing population resilience and the rapid adaptation to environmental changes.

Assisted gene flow: An active intervention which involves transplanting genotypes of a given species from distant sources to new locations within the species range with the potential to restore levels of genetic diversity.

Climate-adjusted provenance: Plant material for restoration collected along a climate gradient in line with climate change projections.

Composite provenance: Plant materials for restoration collected as a mixture from healthy local provenances together with smaller amounts of material from more distant sites.

Effective population size: A measure proposed by Montalvo et al. [199] to evaluate genetic diversity in populations by considering the percentage of reproductive individuals, sex ratio, and fluctuations in population density.

Genetic restoration: The process of assisting the recovery of an ecosystem that has been degraded by restoring or improving the genetic baselines of vulnerable populations.

Genetic rescue: Introduction of genetic materials from other populations to increase the fitness of small, isolated, and imperiled populations.

Heterosis: Increased fitness of hybrid product from two different genotypes in comparison with parental genotypes.

Inbreeding depression: Reduction in survival, fitness and reproduction of offspring of genetically related individuals.

Local provenance: Plant material for the restoration collected near to and in similar environmental conditions as the planting site, which gives new plants the best chance of survival.

Linkage disequilibrium: Non-random association of alleles at different loci. The frequency of association of different alleles is higher or lower than what would be expected if the loci were independent and randomly associated.

Outbreeding depression: Reduction in survival, fitness and reproduction of offspring of genetically distant individuals.

\section{References}

1. Ceballos, G.; Ehrlich, P.R.; Barnosky, A.D.; García, A.; Pringle, R.M.; Palmer, T.M. Accelerated modern human-induced species losses: Entering the sixth mass extinction. Science 2015, 1, e1400253. [CrossRef]

2. Hobbs, R.J.; Higgs, E.S.; Hall, C.M. Expanding the Portfolio: Conserving Nature's Masterpieces in a Changing World. Bioscience 2017, 67, 568-575. [CrossRef]

3. Perring, M.P.; Standish, R.J.; Price, J.N.; Craig, M.D.; Erickson, T.E.; Ruthrof, K.X.; Whiteley, A.S.; Valentine, L.E.; Hobbs, R.J. Advances in restoration ecology: Rising to the challenges of the coming decades. Ecosphere 2015, 6, 1-25. [CrossRef] 
4. Benayas, J.M.R.; Newton, A.C.; Diaz, A.; Bullock, J.M. Enhancement of biodiversity and ecosystem services by ecological restoration: A meta-analysis. Science 2009, 325, 1121-1124. [CrossRef] [PubMed]

5. Reynolds, L.K.; Waycott, M.; McGlathery, K.J.; Orth, R.J. Ecosystem services returned through seagrass restoration. Restor. Ecol. 2016, 24, 583-588. [CrossRef]

6. Wood, G.; Marzinelli, E.M.; Coleman, M.A.; Campbell, A.H.; Santini, N.S.; Kajlich, L.; Verdura, J.; Wodak, J.; Steinberg, P.D.; Vergés, A. Restoring subtidal marine macrophytes in the Anthropocene: Trajectories and future-proofing. Mar. Freshw. Res. 2019, 70, 936-951. [CrossRef]

7. Boström-Einarsson, L.; Babcock, R.C.; Bayraktarov, E.; Ceccarelli, D.; Cook, N.; Ferse, S.C.A.; Hancock, B.; Harrison, P.; Hein, M.; Shaver, E. Coral restoration-A systematic review of current methods, successes, failures and future directions. PLoS ONE 2020, 15, e0226631. [CrossRef]

8. Duarte, C.M.; Agusti, S.; Barbier, E.; Britten, G.L.; Castilla, J.C.; Gattuso, J.-P.; Fulweiler, R.W.; Hughes, T.P.; Knowlton, N.; Lovelock, C.E. Rebuilding marine life. Nature 2020, 580, 39-51. [CrossRef]

9. Layton, C.; Coleman, M.A.; Marzinelli, E.M.; Steinberg, P.D.; Swearer, S.E.; Vergés, A.; Wernberg, T.; Johnson, C.R. Kelp forest restoration in Australia. Front. Mar. Sci. 2020, 7, 74. [CrossRef]

10. Tan, Y.M.; Dalby, O.; Kendrick, G.A.; Statton, J.; Sinclair, E.A.; Fraser, M.W.; Macreadie, P.I.; Gillies, C.L.; Coleman, R.A.; Waycott, M. Seagrass restoration is possible: Insights and lessons from Australia and New Zealand. Front. Mar. Sci. 2020, 7, 617. [CrossRef]

11. Evans, S.M.; Sinclair, E.A.; Poore, A.G.B.; Bain, K.F.; Vergés, A. Assessing the effect of genetic diversity on the early establishment of the threatened seagrass Posidonia australis using a reciprocal-transplant experiment. Restor. Ecol. 2018, 26, 570-580. [CrossRef]

12. Short, F.T.; Carruthers, T.; Dennison, W.; Waycott, M. Global seagrass distribution and diversity: A bioregional model. J. Exp. Mar. Bio. Ecol. 2007, 350, 3-20. [CrossRef]

13. Bertelli, C.M.; Unsworth, R.K.F. Protecting the hand that feeds us: Seagrass (Zostera marina) serves as commercial juvenile fish habitat. Mar. Pollut. Bull. 2014, 83, 425-429. [CrossRef] [PubMed]

14. Nordlund, L.M.; Jackson, E.L.; Nakaoka, M.; Samper-Villarreal, J.; Beca-Carretero, P.; Creed, J.C. Seagrass ecosystem servicesWhat's next? Mar. Pollut. Bull. 2018, 134, 145-151. [CrossRef] [PubMed]

15. Costanza, R.; De Groot, R.; Sutton, P.; Van der Ploeg, S.; Anderson, S.J.; Kubiszewski, I.; Farber, S.; Turner, R.K. Changes in the global value of ecosystem services. Glob. Environ. Chang. 2014, 26, 152-158. [CrossRef]

16. Buia, M.C.; Mazzella, L. Reproductive phenology of the Mediterranean seagrasses Posidonia oceanica (L.) Delile, Cymodocea nodosa (Ucria) Aschers. and Zostera noltii Hornem. Aquat. Bot. 1991, 40, 343-362. [CrossRef]

17. Jahnke, M.; Olsen, J.L.; Procaccini, G. A meta-analysis reveals a positive correlation between genetic diversity metrics and environmental status in the long-lived seagrass Posidonia oceanica. Mol. Ecol. 2015, 24, 2336-2348. [CrossRef]

18. Paulo, D.; Diekmann, O.; Ramos, A.A.; Alberto, F.; Serrão, E.A. Sexual reproduction vs. Clonal propagation in the recovery of a seagrass meadow after an extreme weather event. Sci. Mar. 2019, 83, 357-363. [CrossRef]

19. Marín-Guirao, L.; Entrambasaguas, L.; Ruiz, J.M.; Procaccini, G. Heat-stress induced flowering can be a potential adaptive response to ocean warming for the iconic seagrass Posidonia oceanica. Mol. Ecol. 2019, 28, 1-16. [CrossRef]

20. Pazzaglia, J.; Reusch, T.B.H.; Terlizzi, A.; Marin Guirao, L.; Procaccini, G. Prompt phenotypic plasticity under rapid global changes: The intrinsic force for future seagrasses survival. Evol. Appl. 2021, in press. [CrossRef]

21. Arnaud-Haond, S.; Duarte, C.M.; Diaz-Almela, E.; Marbà, N.; Sintes, T.; Serrão, E.A. Implications of extreme life span in clonal organisms: Millenary clones in meadows of the threatened seagrass posidonia oceanica. PLoS ONE 2012, 7. [CrossRef]

22. Migliaccio, M.; De Martino, F.; Silvestre, F.; Procaccini, G. Meadow-scale genetic structure in Posidonia oceanica. Mar. Ecol. Prog. Ser. 2005, 304, 55-65. [CrossRef]

23. Vallejo-Marín, M.; Dorken, M.E.; Barrett, S.C.H. The Ecological and Evolutionary Consequences of Clonality for Plant Mating. Annu. Rev. Ecol. Evol. Syst. 2010, 41, 193-213. [CrossRef]

24. Ruocco, M.; Entrambasaguas, L.; Dattolo, E.; Milito, A.; Marín-Guirao, L.; Procaccini, G. A king and vassals' tale: Molecular signatures of clonal integration in Posidonia oceanica under chronic light shortage. J. Ecol. 2020, 109, 294-312. [CrossRef]

25. Procaccini, G.; Mazzella, L. Population genetic structure and gene flow in the seagrass Posidonia oceanica assessed using microsatellite analysis. Mar. Ecol. Prog. Ser. 1998, 169, 133-141. [CrossRef]

26. Alberto, F.; Mata, L.; Santos, R. Genetic homogeneity in the seagrass Cymodocea nodosa at its northern Atlantic limit revealed through RAPD. Mar. Ecol. Prog. Ser. 2001, 221, 299-301. [CrossRef]

27. Procaccini, G.; Orsini, L.; Ruggiero, M.V.; Scardi, M. Spatial patterns of genetic diversity in Posidonia oceanica, an endemic Mediterranean seagrass. Mol. Ecol. 2001, 10, 1413-1421. [CrossRef] [PubMed]

28. Marbà, N.; Duarte, C.M. Mediterranean warming triggers seagrass (Posidonia oceanica) shoot mortality. Glob. Chang. Biol. 2010, 16, 2366-2375. [CrossRef]

29. Strydom, S.; Murray, K.; Wilson, S.; Huntley, B.; Rule, M.; Heithaus, M.; Bessey, C.; Kendrick, G.A.; Burkholder, D.; Holmes, T.; et al. Too hot to handle: Unprecedented seagrass death driven by marine heatwave in a World Heritage Area. Glob. Chang. Biol. 2020, 26. [CrossRef]

30. Waycott, M.; Duarte, C.M.; Carruthers, T.J.B.; Orth, R.J.; Dennison, W.C.; Olyarnik, S.; Calladine, A.; Fourqurean, J.W.; Heck, K.L.; Hughes, A.R. Accelerating loss of seagrasses across the globe threatens coastal ecosystems. Proc. Natl. Acad. Sci. USA 2009, 106, 12377-12381. [CrossRef] [PubMed] 
31. Short, F.T.; Polidoro, B.; Livingstone, S.R.; Carpenter, K.E.; Bandeira, S.; Bujang, J.S.; Calumpong, H.P.; Carruthers, T.J.B.; Coles, R.G.; Dennison, W.C. Extinction risk assessment of the world's seagrass species. Biol. Conserv. 2011, 144, 1961-1971. [CrossRef]

32. Pazzaglia, J.; Santillán-Sarmiento, A.; Helber, S.B.; Ruocco, M.; Terlizzi, A.; Marín-Guirao, L.; Procaccini, G. Does Warming Enhance the Effects of Eutrophication in the Seagrass Posidonia oceanica? Front. Mar. Sci. 2020, 7, 1067. [CrossRef]

33. Ruocco, M.; Marín-Guirao, L.; Ravaglioli, C.; Bulleri, F.; Procaccini, G. Molecular level responses to chronic versus pulse nutrient loading in the seagrass Posidonia oceanica undergoing herbivore pressure. Oecologia 2018, 188, 23-39. [CrossRef] [PubMed]

34. Orth, R.J.; Carruthers, T.J.B.; Dennison, W.C.; Duarte, C.M.; Fourqurean, J.W.; Heck, K.L.; Hughes, A.R.; Kendrick, G.A.; Kenworthy, W.J.; Olyarnik, S. A global crisis for seagrass ecosystems. AIBS Bull. 2006, 56, 987-996. [CrossRef]

35. Van Oppen, M.J.H.; Gates, R.D.; Blackall, L.L.; Cantin, N.; Chakravarti, L.J.; Chan, W.Y.; Cormick, C.; Crean, A.; Damjanovic, K.; Epstein, H. Shifting paradigms in restoration of the world's coral reefs. Glob. Chang. Biol. 2017, 23, 3437-3448. [CrossRef]

36. Coleman, M.A.; Wood, G.; Filbee-Dexter, K.; Minne, A.J.P.; Goold, H.D.; Vergés, A.; Marzinelli, E.M.; Steinberg, P.D.; Wernberg, T. Restore or redefine: Future trajectories for restoration. Front. Mar. Sci. 2020, 7, 237. [CrossRef]

37. Abelson, A.; Reed, D.C.; Edgar, G.J.; Smith, C.S.; Kendrick, G.A.; Orth, R.J.; Airoldi, L.; Silliman, B.; Beck, M.W.; Krause, G. Challenges for restoration of coastal marine ecosystems in the Anthropocene. Front. Mar. Sci. 2020, 7, 892. [CrossRef]

38. Fitzpatrick, M.C.; Keller, S.R. Ecological genomics meets community-level modelling of biodiversity: Mapping the genomic landscape of current and future environmental adaptation. Ecol. Lett. 2014, 18, 1-16. [CrossRef] [PubMed]

39. Eisele, F.; Seockhwan Hwang, B. New UN Decade on Ecosystem Restoration offers unparalleled opportunity for job creation, food security and addressing climate change. N. For. 2019, 50, 139-151.

40. Hughes, A.R.; Inouye, B.D.; Johnson, M.T.J.; Underwood, N.; Vellend, M. Ecological consequences of genetic diversity. Ecol. Lett. 2008, 11, 609-623. [CrossRef]

41. Ferber, S.; Stam, W.T.; Olsen, J.L. Genetic diversity and connectivity remain high in eelgrass Zostera marina populations in the Wadden Sea, despite major impacts. Mar. Ecol. Prog. Ser. 2008, 372, 87-96. [CrossRef]

42. Bricker, E.; Waycott, M.; Calladine, A.; Zieman, J.C. High connectivity across environmental gradients and implications for phenotypic plasticity in a marine plant. Mar. Ecol. Prog. Ser. 2011, 423, 57-67. [CrossRef]

43. Larkum, A.W.D.; Orth, R.J.; Duarte, C.M. Seagrasses: Biology, ecology and conservation. Seagrasses Biol. Ecol. Conserv. 2006, 1-691. [CrossRef]

44. Den Hartog, C. Sea-Grasses of the World; North-Holland Publication Co.: Amsterdam, The Netherlands, 1970.

45. Les, D.H.; Cleland, M.A.; Waycott, M. Phylogenetic studies in Alismatidae, II: Evolution of marine angiosperms (seagrasses) and hydrophily. Syst. Bot. 1997, 22, 443-463. [CrossRef]

46. Reusch, T.B.H. Five microsatellite loci in eelgrass Zostera marina and a test of cross-species amplification in Z. noltii and Z. japonica. Mol. Ecol. 2000, 9, 371-373. [CrossRef] [PubMed]

47. Ruggiero, M.V.; Capone, S.; Pirozzi, P.; Reusch, T.B.H.; Procaccini, G. Mating system and clonal architecture: A comparative study in two marine angiosperms. Evol. Ecol. 2005, 19, 487-499. [CrossRef]

48. Zipperle, A.M.; Coyer, J.A.; Reise, K.; Stam, W.T.; Olsen, J.L. An evaluation of small-scale genetic diversity and the mating system in Zostera noltii on an intertidal sandflat in the Wadden Sea. Ann. Bot. 2011, 107, 127-134. [CrossRef] [PubMed]

49. Evans, S.M.; Sinclair, E.A.; Poore, A.G.B.; Steinberg, P.D.; Kendrick, G.A.; Vergés, A. Genetic diversity in threatened Posidonia australis seagrass meadows. Conserv. Genet. 2014, 15, 717-728. [CrossRef]

50. Arnaud-Haond, S.; Stoeckel, S.; Bailleul, D. New insights into the population genetics of partially clonal organisms: When seagrass data meet theoretical expectations. Mol. Ecol. 2020, 29, 3248-3260. [CrossRef]

51. Reusch, T.B.H.; Boström, C. Widespread genetic mosaicism in the marine angiosperm Zostera marina is correlated with clonal reproduction. Evol. Ecol. 2011, 25, 899-913. [CrossRef]

52. Harper, J.L. Population Biology of Plants; CABI: Wallingford, UK, 1977.

53. Yu, L.; Boström, C.; Franzenburg, S.; Bayer, T.; Dagan, T.; Reusch, T.B.H. Somatic genetic drift and multi-level selection in modular species. Nat. Ecol. Evol. 2020, 4, 952-962. [CrossRef]

54. Kendrick, G.A.; Orth, R.J.; Statton, J.; Hovey, R.; Montoya, L.R.; Lowe, R.J.; Krauss, S.L.; Sinclair, E.A. Demographic and genetic connectivity: The role and consequences of reproduction, dispersal and recruitment in seagrasses. Biol. Rev. 2017, 92, 921-938. [CrossRef]

55. Tomasello, A.; Di Maida, G.; Calvo, S.; Pirrotta, M.; Borra, M.; Procaccini, G. Seagrass meadows at the extreme of environmental tolerance: The case of Posidonia oceanica in a semi-enclosed coastal lagoon. Mar. Ecol. 2009, 30, 288-300. [CrossRef]

56. Serra, I.A.; Innocenti, A.M.; Di Maida, G.; Calvo, S.; Migliaccio, M.; Zambianchi, E.; Pizzigalli, C.; Arnaud-Haond, S.; Duarte, C.M.; Serrao, E.A. Genetic structure in the Mediterranean seagrass Posidonia oceanica: Disentangling past vicariance events from contemporary patterns of gene flow. Mol. Ecol. 2010, 19, 557-568. [CrossRef]

57. Jahnke, M.; Casagrandi, R.; Melià, P.; Schiavina, M.; Schultz, S.T.; Zane, L.; Procaccini, G. Potential and realized connectivity of the seagrass Posidonia oceanica and their implication for conservation. Divers. Distrib. 2017, 23, 1423-1434. [CrossRef]

58. Mari, L.; Melià, P.; Fraschetti, S.; Gatto, M.; Casagrandi, R. Spatial patterns and temporal variability of seagrass connectivity in the Mediterranean Sea. Divers. Distrib. 2020, 26, 169-182. [CrossRef]

59. Kendrick, G.A.; Waycott, M.; Carruthers, T.J.B.; Cambridge, M.L.; Hovey, R.; Krauss, S.L.; Lavery, P.S.; Les, D.H.; Lowe, R.J.; Vidal, O.M.I. The central role of dispersal in the maintenance and persistence of seagrass populations. Bioscience 2012, 62, 56-65. [CrossRef] 
60. Alotaibi, N.M.; Kenyon, E.J.; Cook, K.J.; Börger, L.; Bull, J.C. Low genotypic diversity and long-term ecological decline in a spatially structured seagrass population. Sci. Rep. 2019, 9, 1-11. [CrossRef]

61. Willi, Y.; Van Buskirk, J.; Schmid, B.; Fischer, M. Genetic isolation of fragmented populations is exacerbated by drift and selection. J. Evol. Biol. 2007, 20, 534-542. [CrossRef]

62. Bijlsma, R.; Loeschcke, V. Genetic erosion impedes adaptive responses to stressful environments. Evol. Appl. 2012, 5, 117-129. [CrossRef]

63. Kawecki, T.J.; Ebert, D. Conceptual issues in local adaptation. Ecol. Lett. 2004, 7, 1225-1241. [CrossRef]

64. Fournier-Level, A.; Korte, A.; Cooper, M.D.; Nordborg, M.; Schmitt, J.; Wilczek, A.M. A map of local adaptation in Arabidopsis thaliana. Science 2011, 334, 86-89. [CrossRef] [PubMed]

65. Savolainen, O.; Lascoux, M.; Merilä, J. Ecological genomics of local adaptation. Nat. Rev. Genet. 2013, 14, 807-820. [CrossRef] [PubMed]

66. Tiffin, P.; Ross-Ibarra, J. Advances and limits of using population genetics to understand local adaptation. Trends Ecol. Evol. 2014, 29, 673-680. [CrossRef] [PubMed]

67. Franssen, S.U.; Gu, J.; Bergmann, N.; Winters, G.; Klostermeier, U.C.; Rosenstiel, P.; Bornberg-Bauer, E.; Reusch, T.B.H. Transcriptomic resilience to global warming in the seagrass Zostera marina, a marine foundation species. Proc. Natl. Acad. Sci. USA 2011, 108, 19276-19281. [CrossRef] [PubMed]

68. Franssen, S.U.; Gu, J.; Winters, G.; Huylmans, A.-K.; Wienpahl, I.; Sparwel, M.; Coyer, J.A.; Olsen, J.L.; Reusch, T.B.H.; BornbergBauer, E. Genome-wide transcriptomic responses of the seagrasses Zostera marina and Nanozostera noltii under a simulated heatwave confirm functional types. Mar. Genom. 2014, 15, 65-73. [CrossRef]

69. Marín-Guirao, L.; Bernardeau-Esteller, J.; García-Muñoz, R.; Ramos, A.; Ontoria, Y.; Romero, J.; Pérez, M.; Ruiz, J.M.; Procaccini, G. Carbon economy of Mediterranean seagrasses in response to thermal stress. Mar. Pollut. Bull. 2018, 135, 617-629. [CrossRef]

70. Marín-Guirao, L.; Entrambasaguas, L.; Dattolo, E.; Ruiz, J.M.; Procaccini, G. Molecular mechanisms behind the physiological resistance to intense transient warming in an iconic marine plant. Front. Plant. Sci. 2017, 8, 1142. [CrossRef]

71. Dattolo, E.; Marín-Guirao, L.; Ruiz, J.M.; Procaccini, G.; Marín-Guirao, L.; Ruiz, J.M.; Procaccini, G. Long-term acclimation to reciprocal light conditions suggests depth-related selection in the marine foundation species Posidonia oceanica. Ecol. Evol. 2017, 7, 1148-1164. [CrossRef]

72. Bernard, A.; Marrano, A.; Donkpegan, A.; Brown, P.J.; Leslie, C.A.; Neale, D.B.; Lheureux, F.; Dirlewanger, E. Association and linkage mapping to unravel genetic architecture of phenological traits and lateral bearing in Persian walnut (Juglans regia L.). BMC Genom. 2020, 21, 1-25. [CrossRef]

73. Jahnke, M.; D’Esposito, D.; Orrù, L.; Lamontanara, A.; Dattolo, E.; Badalamenti, F.; Mazzuca, S.; Procaccini, G.; Orsini, L. Adaptive responses along a depth and a latitudinal gradient in the endemic seagrass Posidonia oceanica. Heredity 2019, 122, $233-243$. [CrossRef]

74. Hughes, A.R.; Stachowicz, J.J. Genetic diversity enhances the resistance of a seagrass ecosystem to disturbance. Proc. Natl. Acad. Sci. USA 2004, 101, 8998-9002. [CrossRef] [PubMed]

75. Reusch, T.B.H.; Ehlers, A.; Hämmerli, A.; Worm, B. Ecosystem recovery after climatic extremes enhanced by genotypic diversity. Proc. Natl. Acad. Sci. USA 2005, 102, 2826-2831. [CrossRef]

76. Ehlers, A.; Worm, B.; Reusch, T.B.H. Importance of genetic diversity in eelgrass Zostera marina for its resilience to global warming. Mar. Ecol. Prog. Ser. 2008, 355, 1-7. [CrossRef]

77. Evans, S.M.; Vergés, A.; Poore, A.G.B. Genotypic diversity and short-term response to shading stress in a threatened seagrass: Does low diversity mean low resilience? Front. Plant. Sci. 2017, 8, 1417. [CrossRef] [PubMed]

78. Connolly, R.M.; Smith, T.M.; Maxwell, P.S.; Olds, A.D.; Macreadie, P.I.; Sherman, C.D.H. Highly disturbed populations of seagrass show increased resilience but lower genotypic diversity. Front. Plant. Sci. 2018, 9, 894. [CrossRef] [PubMed]

79. Crutsinger, G.M.; Collins, M.D.; Fordyce, J.A.; Gompert, Z.; Nice, C.C.; Sanders, N.J. Plant genotypic diversity predicts community structure and governs an ecosystem process. Science 2006, 313, 966-968. [CrossRef] [PubMed]

80. Whitlock, R. Relationships between adaptive and neutral genetic diversity and ecological structure and functioning: A metaanalysis. J. Ecol. 2014, 102, 857-872. [CrossRef] [PubMed]

81. Williams, S.L. Reduced genetic diversity in eelgrass transplantations affects both population growth and individual fitness. Ecol. Appl. 2001, 11, 1472-1488. [CrossRef]

82. Jahnke, M.; Serra, I.A.; Bernard, G.; Procaccini, G. The importance of genetic make-up in seagrass restoration: A case study of the seagrass Zostera noltei. Mar. Ecol. Prog. Ser. 2015, 532, 111-122. [CrossRef]

83. Reynolds, L.K.; Waycott, M.; McGlathery, K.J.; Orth, R.J.; Zieman, J.C. Eelgrass restoration by seed maintains genetic diversity: Case study from a coastal bay system. Mar. Ecol. Prog. Ser. 2012, 448, 223-233. [CrossRef]

84. Reynolds, L.K.; McGlathery, K.J.; Waycott, M. Genetic diversity enhances restoration success by augmenting ecosystem services. PLoS ONE 2012, 7, e38397. [CrossRef] [PubMed]

85. Sinclair, E.A.; Verduin, J.; Krauss, S.L.; Hardinge, J.; Anthony, J.; Kendrick, G.A. A genetic assessment of a successful seagrass meadow (Posidonia australis) restoration trial. Ecol. Manag. Restor. 2013, 14, 68-71. [CrossRef]

86. Campanella, J.J.; Bologna, P.A.X.; Smalley, J.V.; Avila, D.N.; Lee, K.N.; Areche, E.C.; Slavin, L.J. An analysis of the population genetics of restored Zostera marina plantings in Barnegat Bay, New Jersey. Popul. Ecol. 2013, 55, 121-133. [CrossRef] 
87. Hämmerli, A.; Reusch, T.B.H. Local adaptation and transplant dominance in genets of the marine clonal plant Zostera marina. Mar. Ecol. Prog. Ser. 2002, 242, 111-118. [CrossRef]

88. Reynolds, L.K.; Waycott, M.; McGlathery, K.J. Restoration recovers population structure and landscape genetic connectivity in a dispersal-limited ecosystem. J. Ecol. 2013, 101, 1288-1297. [CrossRef]

89. Procaccini, G.; Piazzi, L. Genetic polymorphism and transplantation success in the Mediterranean seagrass Posidonia oceanica. Restor. Ecol. 2001, 9, 332-338. [CrossRef]

90. Travis, S.E.; Sheridan, P. Genetic structure of natural and restored shoalgrass Halodule wrightii populations in the NW Gulf of Mexico. Mar. Ecol. Prog. Ser. 2006, 322, 117-127. [CrossRef]

91. Williams, S.L.; Davis, C.A. Population genetic analyses of transplanted eelgrass (Zostera marina) beds reveal reduced genetic diversity in southern California. Restor. Ecol. 1996, 4, 163-180. [CrossRef]

92. Sgrò, C.M.; Lowe, A.J.; Hoffmann, A.A. Building evolutionary resilience for conserving biodiversity under climate change. Evol. Appl. 2011, 4, 326-337. [CrossRef] [PubMed]

93. Breed, M.F.; Harrison, P.A.; Bischoff, A.; Durruty, P.; Gellie, N.J.C.; Gonzales, E.K.; Havens, K.; Karmann, M.; Kilkenny, F.F.; Krauss, S.L. Priority actions to improve provenance decision-making. Bioscience 2018, 68, 510-516. [CrossRef]

94. Broadhurst, L.M.; Lowe, A.; Coates, D.J.; Cunningham, S.A.; McDonald, M.; Vesk, P.A.; Yates, C. Seed supply for broadscale restoration: Maximizing evolutionary potential. Evol. Appl. 2008, 1, 587-597. [CrossRef] [PubMed]

95. Aitken, S.N.; Whitlock, M.C. Assisted gene flow to facilitate local adaptation to climate change. Annu. Rev. Ecol. Evol. Syst. 2013, 44, 367-388. [CrossRef]

96. Nguyen, V.X.; Detcharoen, M.; Tuntiprapas, P.; Soe-Htun, U.; Sidik, J.B.; Harah, M.Z.; Prathep, A.; Papenbrock, J. Genetic species identification and population structure of Halophila (Hydrocharitaceae) from the Western Pacific to the Eastern Indian Ocean. BMC Evol. Biol. 2014, 14, 1-18. [CrossRef] [PubMed]

97. Todesco, M.; Pascual, M.A.; Owens, G.L.; Ostevik, K.L.; Moyers, B.T.; Hübner, S.; Heredia, S.M.; Hahn, M.A.; Caseys, C.; Bock, D.G. Hybridization and extinction. Evol. Appl. 2016, 9, 892-908. [CrossRef]

98. Liu, S.Y.V.; Kumara, T.P.; Hsu, C.-H. Genetic identification and hybridization in the seagrass genus Halophila (Hydrocharitaceae) in Sri Lankan waters. PeerJ 2020, 8, e10027. [CrossRef]

99. Prober, S.M.; Byrne, M.; McLean, E.H.; Steane, D.A.; Potts, B.M.; Vaillancourt, R.E.; Stock, W.D. Climate-adjusted provenancing: A strategy for climate-resilient ecological restoration. Front. Ecol. Evol. 2015, 3, 65. [CrossRef]

100. Green, E.P.; Short, F.T.; Frederick, T. The World Atlas of Seagrasses; University of California Press: Berkeley, CA, USA, 2003.

101. Vander Mijnsbrugge, K.; Bischoff, A.; Smith, B. A question of origin: Where and how to collect seed for ecological restoration. Basic Appl. Ecol. 2010, 11, 300-311. [CrossRef]

102. McMahon, K.; Sinclair, E.A.; Sherman, C.D.H.; Van Dijk, K.-J.; Hernawan, U.E.; Verduin, J.; Waycott, M. Genetic connectivity in tropical and temperate Australian seagrass species. In Seagrasses of Australia; Springer: Berlin/Heidelberg, Germany, 2018; pp. 155-194.

103. Arnaud-Haond, S.; Migliaccio, M.; Diaz-Almela, E.; Teixeira, S.; Van De Vliet, M.S.; Alberto, F.; Procaccini, G.; Duarte, C.M.; Serrão, E.A. Vicariance patterns in the Mediterranean Sea: East-west cleavage and low dispersal in the endemic seagrass Posidonia Oceanica. J. Biogeogr. 2007, 34, 963-976. [CrossRef]

104. Procaccini, G.; Olsen, J.L.; Reusch, T.B.H. Contribution of genetics and genomics to seagrass biology and conservation. J. Exp. Mar. Bio. Ecol. 2007, 350, 234-259. [CrossRef]

105. Lanuru, M.; Mashoreng, S.; Amri, K. Using site-selection model to identify suitable sites for seagrass transplantation in the west coast of South Sulawesi. J. Phys. Conf. Ser. 2018, 979, 12007. [CrossRef]

106. Ferdinando, B.; Federica, F.; Simona, F.; Paul, G.; Macpherson, E.; Serge, P.; Takvor, S. CoCoNet: Towards coast to coast networks of marine protected areas (from the shore to the high and deep sea), coupled with sea-based wind energy potential. Sci. Res. Inf. Technol. 2016, 6, 1-96.

107. Valle, M.; Chust, G.; Del Campo, A.; Wisz, M.S.; Olsen, S.M.; Garmendia, J.M.; Borja, Á. Projecting future distribution of the seagrass Zostera noltii under global warming and sea level rise. Biol. Conserv. 2014, 170, 74-85. [CrossRef]

108. Chefaoui, R.M.; Assis, J.; Duarte, C.M.; Serrão, E.A. Large-Scale Prediction of Seagrass Distribution Integrating Landscape Metrics and Environmental Factors: The Case of Cymodocea nodosa (Mediterranean-Atlantic). Estuaries Coasts 2016, 39, 123-137. [CrossRef]

109. Oreska, M.P.J.; McGlathery, K.J.; Wiberg, P.L.; Orth, R.J.; Wicox, D.J. Defining the Zostera marina (Eelgrass) Niche from Long-Term Success of Restored and Naturally Colonized Meadows: Implications for Seagrass Restoration. Estuaries Coasts 2021, 44, 396-411. [CrossRef]

110. McKay, J.K.; Christian, C.E.; Harrison, S.; Rice, K.J. How local is local? A review of practical and conceptual issues in the genetics of restoration. Restor. Ecol. 2005, 13, 432-440. [CrossRef]

111. Sinclair, E.A.; Edgeloe, J.M.; Anthony, J.M.; Statton, J.; Breed, M.F.; Kendrick, G.A. Variation in reproductive effort, genetic diversity and mating systems across Posidonia australis seagrass meadows in Western Australia. AoB Plants 2020, 12, plaa038. [CrossRef] [PubMed]

112. Sexton, J.P.; Strauss, S.Y.; Rice, K.J. Gene flow increases fitness at the warm edge of a specie's range. Proc. Natl. Acad. Sci. USA 2011, 108, 11704-11709. [CrossRef] 
113. Sinclair, E.A.; Anthony, J.M.; Greer, D.; Ruiz-Montoya, L.; Evans, S.M.; Krauss, S.L.; Kendrick, G.A. Genetic signatures of Bassian glacial refugia and contemporary connectivity in a marine foundation species. J. Biogeogr. 2016, 43, 2209-2222. [CrossRef]

114. Campanella, J.J.; Bologna, P.A.X.; Smith, S.M.; Rosenzweig, E.B.; Smalley, J.V. Zostera marina population genetics in Barnegat Bay, New Jersey, and implications for grass bed restoration. Popul. Ecol. 2010, 52, 181-190. [CrossRef]

115. Kim, J.H.; Kang, J.H.; Jang, J.E.; Choi, S.K.; Kim, M.J.; Park, S.R.; Lee, H.J. Population genetic structure of eelgrass (Zostera marina) on the Korean coast: Current status and conservation implications for future management. PLoS ONE 2017, 12, e0174105. [CrossRef]

116. Smith, T.M.; York, P.H.; Macreadie, P.I.; Keough, M.J.; Ross, D.J.; Sherman, C.D.H. Spatial variation in reproductive effort of a southern Australian seagrass. Mar. Environ. Res. 2016, 120, 214-224. [CrossRef]

117. Procaccini, G.; Ruocco, M.; Marín-Guirao, L.; Dattolo, E.; Brunet, C.; D’Esposito, D.; Lauritano, C.; Mazzuca, S.; Serra, I.A.; Bernardo, L.; et al. Depth-specific fluctuations of gene expression and protein abundance modulate the photophysiology in the seagrass Posidonia oceanica. Sci. Rep. 2017, 7. [CrossRef]

118. D'Esposito, D.; Dattolo, E.; Badalamenti, F.; Orsini, L.; Procaccini, G. Comparative analysis of genetic diversity of posidonia oceanica along a depth gradient using neutral and selective/non neutral microsatellites markers. Biol. Mar. Mediterr. 2012, 19, 45.

119. Telesca, L.; Belluscio, A.; Criscoli, A.; Ardizzone, G.; Apostolaki, E.T.; Fraschetti, S.; Gristina, M.; Knittweis, L.; Martin, C.S.; Pergent, G. Seagrass meadows (Posidonia oceanica) distribution and trajectories of change. Sci. Rep. 2015, 5, 12505. [CrossRef] [PubMed]

120. Micheli, F.; Halpern, B.S.; Walbridge, S.; Ciriaco, S.; Ferretti, F.; Fraschetti, S.; Lewison, R.; Nykjaer, L.; Rosenberg, A.A. Cumulative human impacts on Mediterranean and Black Sea marine ecosystems: Assessing current pressures and opportunities. PLoS ONE 2013, 8, e79889. [CrossRef] [PubMed]

121. Jahnke, M.F. Population Connectivity and Genetic Diversity in Mediterranean Seagrasses in the Framework of Management and Conservation of the Coastline. Ph.D. Thesis, The Open University, Milton Keynes, UK, September 2015.

122. Van Katwijk, M.M.; Thorhaug, A.; Marbà, N.; Orth, R.J.; Duarte, C.M.; Kendrick, G.A.; Althuizen, I.H.J.; Balestri, E.; Bernard, G.; Cambridge, M.L.; et al. Global analysis of seagrass restoration: The importance of large-scale planting. J. Appl. Ecol. 2016, 53, 567-578. [CrossRef]

123. Kettenring, K.M.; Tarsa, E.E. Need to seed? Ecological, genetic, and evolutionary keys to seed-based wetland restoration. Front. Environ. Sci. 2020, 8, 109. [CrossRef]

124. Orth, R.J.; Moore, K.A.; Marion, S.R.; Wilcox, D.J.; Parrish, D.B. Seed addition facilitates eelgrass recovery in a coastal bay system. Mar. Ecol. Prog. Ser. 2012, 448, 177-195. [CrossRef]

125. Orth, R.J.; Lefcheck, J.S.; McGlathery, K.S.; Aoki, L.; Luckenbach, M.W.; Moore, K.A.; Oreska, M.P.J.; Snyder, R.; Wilcox, D.J.; Lusk, B. Restoration of seagrass habitat leads to rapid recovery of coastal ecosystem services. Sci. Adv. 2020, 6, 1-10. [CrossRef]

126. Marion, S.R.; Orth, R.J. Innovative Techniques for large-scale seagrass restoration using Zostera marina (eelgrass) seeds. Restor. Ecol. 2010, 18, 514-526. [CrossRef]

127. Statton, J.; Montoya, L.R.; Orth, R.J.; Dixon, K.W.; Kendrick, G.A. Identifying critical recruitment bottlenecks limiting seedling establishment in a degraded seagrass ecosystem. Sci. Rep. 2017, 7, 1-12. [CrossRef]

128. Orth, R.J.; Luckenbach, M.L.; Marion, S.R.; Moore, K.A.; Wilcox, D.J. Seagrass recovery in the Delmarva coastal bays, USA. Aquat. Bot. 2006, 84, 26-36. [CrossRef]

129. Van Rossum, F.; Hardy, O.J.; Le Pajolec, S.; Raspé, O. Genetic monitoring of translocated plant populations in practice. Mol. Ecol. 2020, 29, 4040-4058. [CrossRef]

130. Lindenmayer, D. Improving restoration programs through greater connection with ecological theory and better monitoring. Front. Ecol. Evol. 2020, 8, 50. [CrossRef]

131. Cook, C.N.; Sgrò, C.M. Understanding managers' and scientists' perspectives on opportunities to achieve more evolutionarily enlightened management in conservation. Evol. Appl. 2018, 11, 1371-1388. [CrossRef]

132. Schwartz, M.K.; Luikart, G.; Waples, R.S. Genetic monitoring as a promising tool for conservation and management. Trends Ecol. Evol. 2007, 22, 25-33. [CrossRef] [PubMed]

133. Mijangos, J.L.; Pacioni, C.; Spencer, P.B.S.; Craig, M.D. Contribution of genetics to ecological restoration. Mol. Ecol. 2015, $24,22-37$. [CrossRef] [PubMed]

134. Jackson, E.L.; Smith, T.M.; York, P.H.; Nielsen, J.; Irving, A.D.; Sherman, C.D.H. An assessment of the seascape genetic structure and hydrodynamic connectivity for subtropical seagrass restoration. Restor. Ecol. 2020, 29, e13269. [CrossRef]

135. Hori, M.; Sato, M. Genetic effects of eelgrass restoration efforts by fisher's seeding to recover seagrass beds as an important natural capital for coastal ecosystem services. Popul. Ecol. 2021, 63, 92-101. [CrossRef]

136. Birchler, J.A.; Yao, H.; Chudalayandi, S.; Vaiman, D.; Veitia, R.A. Heterosis. Plant. Cell 2010, 22, 2105-2112. [CrossRef]

137. Statton, J.; Dixon, K.W.; Hovey, R.K.; Kendrick, G.A. A comparative assessment of approaches and outcomes for seagrass revegetation in Shark Bay and Florida Bay. Mar. Freshw. Res. 2012, 63, 984-993. [CrossRef]

138. Procaccini, G.; Beer, S.; Björk, M.; Olsen, J.; Mazzuca, S.; Santos, R. Seagrass ecophysiology meets ecological genomics: Are we ready? Mar. Ecol. 2012, 33, 522-527. [CrossRef]

139. Merilä, J.; Hendry, A.P. Climate change, adaptation, and phenotypic plasticity: The problem and the evidence. Evol. Appl. 2014, 7, 1-14. [CrossRef] 
140. Van Oppen, M.J.H.; Oliver, J.K.; Putnam, H.M.; Gates, R.D. Building coral reef resilience through assisted evolution. Proc. Natl. Acad. Sci. USA 2015, 112, 2307-2313. [CrossRef] [PubMed]

141. Jones, T.A.; Monaco, T.A. A role for assisted evolution in designing native plant materials for domesticated landscapes. Front. Ecol. Environ. 2009, 7, 541-547. [CrossRef]

142. Anderson, K.; Taylor, D.A.; Thompson, E.L.; Melwani, A.R.; Nair, S.V.; Raftos, D.A. Meta-analysis of studies using suppression subtractive hybridization and microarrays to investigate the effects of environmental stress on gene transcription in oysters. PLoS ONE 2015, 10, e0118839. [CrossRef]

143. Fernandez i Marti, A.; Dodd, R.S. Using CRISPR as a gene editing tool for validating adaptive gene function in tree landscape genomics. Front. Ecol. Evol. 2018, 6, 76. [CrossRef]

144. Breed, M.F.; Harrison, P.A.; Blyth, C.; Byrne, M.; Gaget, V.; Gellie, N.J.C.; Groom, S.V.C.; Hodgson, R.; Mills, J.G.; Prowse, T.A.A. The potential of genomics for restoring ecosystems and biodiversity. Nat. Rev. Genet. 2019, 20, 615-628. [CrossRef]

145. Hartung, F.; Schiemann, J. Precise plant breeding using new genome editing techniques: Opportunities, safety and regulation in the EU. Plant. J. 2014, 78, 742-752. [CrossRef] [PubMed]

146. Tanner, C.E.; Parham, T. Growing Zostera marina (eelgrass) from seeds in land-based culture systems for use in restoration projects. Restor. Ecol. 2010, 18, 527-537. [CrossRef]

147. Jisha, K.C.; Vijayakumari, K.; Puthur, J.T. Seed priming for abiotic stress tolerance: An overview. Acta Physiol. Plant. 2013, 35, 1381-1396. [CrossRef]

148. Vriet, C.; Hennig, L.; Laloi, C. Stress-induced chromatin changes in plants: Of memories, metabolites and crop improvement. Cell. Mol. Life Sci. 2015, 72, 1261-1273. [CrossRef]

149. Nguyen, H.M.; Kim, M.; Ralph, P.J.; Marín-Guirao, L.; Pernice, M.; Procaccini, G. Stress memory in seagrasses: First insight into the effects of thermal priming and the role of epigenetic modifications. Front. Plant. Sci. 2020, 11, 494. [CrossRef]

150. Jueterbock, A.; Boström, C.; Coyer, J.A.; Olsen, J.L.; Kopp, M.; Dhanasiri, A.K.S.; Smolina, I.; Arnaud-Haond, S.; Van de Peer, Y.; Hoarau, G. The seagrass methylome is associated with variation in photosynthetic performance among clonal shoots. Front. Plant. Sci. 2020, 11, 1387. [CrossRef] [PubMed]

151. Bossdorf, O.; Richards, C.L.; Pigliucci, M. Epigenetics for ecologists. Ecol. Lett. 2008, 11, 106-115. [CrossRef] [PubMed]

152. Richards, C.L.; Alonso, C.; Becker, C.; Bossdorf, O.; Bucher, E.; Colomé-Tatché, M.; Durka, W.; Engelhardt, J.; Gaspar, B.; GogolDöring, A.; et al. Ecological plant epigenetics: Evidence from model and non-model species, and the way forward. Ecol. Lett. 2017, 20, 1576-1590. [CrossRef] [PubMed]

153. Holliday, R. Epigenetics: A historical overview. Epigenetics 2006, 1, 76-80. [CrossRef] [PubMed]

154. Herman, J.J.; Spencer, H.G.; Donohue, K.; Sultan, S.E. How stable 'should'epigenetic modifications be? Insights from adaptive plasticity and bet hedging. Evolution 2014, 68, 632-643. [CrossRef]

155. Douhovnikoff, V.; Dodd, R.S. Epigenetics: A potential mechanism for clonal plant success. Plant. Ecol. 2015, 216, 227-233. [CrossRef]

156. Dodd, R.S.; Douhovnikoff, V. Adjusting to global change through clonal growth and epigenetic variation. Front. Ecol. Evol. 2016, 4, 86. [CrossRef]

157. Verhoeven, K.J.F.; Preite, V. Epigenetic variation in asexually reproducing organisms. Evolution 2014, 68, 644-655. [CrossRef]

158. Greco, M.; Chiappetta, A.; Bruno, L.; Bitonti, M.B. In Posidonia oceanica cadmium induces changes in DNA methylation and chromatin patterning. J. Exp. Bot. 2012, 63, 695-709. [CrossRef]

159. Greco, M.; Chiappetta, A.; Bruno, L.; Bitonti, M.B. Effects of light deficiency on genome methylation in Posidonia oceanica. Mar. Ecol. Prog. Ser. 2013, 473, 103-114. [CrossRef]

160. Ruocco, M.; Marín-Guirao, L.; Procaccini, G. Within and among-leaf variations in photo-physiological functions, gene expression and DNA methylation patterns in the large-sized seagrass Posidonia oceanica. Mar. Biol. 2019, 166, 24. [CrossRef]

161. Latzel, V.I.T.; Allan, E.; Silveira, A.B.; Colot, V.; Fischer, M.; Bossdorf, O. Epigenetic diversity increases the productivity and stability of plant populations. Nat. Commun. 2013, 4, 2875. [CrossRef]

162. Gáspár, B.; Bossdorf, O.; Durka, W. Structure, stability and ecological significance of natural epigenetic variation: A large-scale survey in Plantago lanceolata. N. Phytol. 2019, 221, 1585-1596. [CrossRef]

163. Rey, O.; Eizaguirre, C.; Angers, B.; Baltazar-Soares, M.; Sagonas, K.; Prunier, J.G.; Blanchet, S. Linking epigenetics and biological conservation: Towards a conservation epigenetics perspective. Funct. Ecol. 2020, 34, 414-427. [CrossRef]

164. Farber, S.; Costanza, R.; Childers, D.L.; Erickson, J.; Gross, K.; Grove, M.; Hopkinson, C.S.; Kahn, J.; Pincetl, S.; Troy, A.; et al. Linking ecology and economics for ecosystem management. Bioscience 2006, 56, 121-133. [CrossRef]

165. Prach, K.; Tolvanen, A. How can we restore biodiversity and ecosystem services in mining and industrial sites? Environ. Sci. Pollut. Res. 2016, 23, 13587-13590. [CrossRef] [PubMed]

166. Laikre, L.; Allendorf, F.W.; Aroner, L.C.; Baker, C.S.; Gregovich, D.P.; Hansen, M.M.; Jackson, J.A.; Kendall, K.C.; Mckelvey, K.; Neel, M.C. Neglect of genetic diversity in implementation of the convention on biological diversity. Conserv. Biol. 2010, 24, 86-88. [CrossRef] [PubMed]

167. De Los Santos, C.B.; Sigurðardóttir, R.; Cunha, A.; Cook, K.; Wiktor, J.M.; Tatarek, A.; Santos, R. A survey-based assessment of seagrass status, management and legislation in Europe. Front. Mar. Sci. Int. Meet. Mar. Res. 2014, 1. [CrossRef] 
168. FAO New United Nations Decade on Ecosystem Restoration Offers Unparalleled Opportunity for Job Creation, Food Security and Addressing Climate Change. Available online: http:/ /www.fao.org/news/story/en/item/1182090/icode (accessed on 10 October 2020).

169. Secretariat of the Convention on Biological Diversity. Bonn Guidelines on Access to Genetic Resources and Fair and Equitable Sharing of the Benefits Arising out of their Utilization; Secretariat of the Convention on Biological Diversity: Montreal, QC, Canada, 2002.

170. Text And Annex of the Nagoya Protocol on Access to Genetic Resources and the Fair and Equitable Sharing of Benefits Arising from their Utilization to the Convention on Biological Diversity, 1st ed.; United Nations: Montreal, QC, Canada, 2015; Available online: https:/ / www.cbd.int/abs/text/default.shtml (accessed on 10 November 2020).

171. Zhu, Y.; Chen, H.; Fan, J.; Wang, Y.; Li, Y.; Chen, J.; Fan, J.X.; Yang, S.; Hu, L.; Leung, H.; et al. Genetic diversity and disease control in rice. Nature 2000, 406, 718-722. [CrossRef] [PubMed]

172. Wood, D.; Lenné, J.M. Agrobiodiversity: Characterization, Utilization and Management; CABI: Wallingford, UK, 1999; ISBN 0851993370 .

173. Tilford, D.S. Saving the blueprints: The international legal regime for plant resources. J. Int. Law 1998, $30,373$.

174. Guerrant, E.O.; Havens, K.; Maunder, M.; Havens, K. Ex Situ Plant. Conservation: Supporting Species Survival in the Wild; Island Press: Washington, DC, USA, 2004.

175. Walck, J.L.; Baskin, J.M.; Baskin, C.C.; Hidayati, S.N. Defining transient and persistent seed banks in species with pronounced seasonal dormancy and germination patterns. Seed Sci. Res. 2005, 15, 189-196. [CrossRef]

176. Falk, D.A.; Holsinger, K.E. Genetic sampling guidelines for conservation collections of endangered plants. In Genetics and Conservation of Rare Plants; Oxford University Press: New York, NY, USA, 1991.

177. IUCN RSG. IUCN Guidelines for Reintroductions and other Conservation Translocations; IUCN: Gland, Switzerland, 2012.

178. Filbee-Dexter, K.; Smajdor, A. Ethics of assisted evolution in marine conservation. Front. Mar. Sci. 2019, 6, 1-6. [CrossRef]

179. Agarwal, M.; Shrivastava, N.; Padh, H. Advances in molecular marker techniques and their applications in plant sciences. Plant. Cell Rep. 2008, 27, 617-631. [CrossRef]

180. Davey, J.W.; Hohenlohe, P.A.; Etter, P.D.; Boone, J.Q.; Catchen, J.M.; Blaxter, M.L. Genome-wide genetic marker discovery and genotyping using next-generation sequencing. Nat. Rev. Genet. 2011, 12, 499-510. [CrossRef]

181. Ekblom, R.; Galindo, J. Applications of next generation sequencing in molecular ecology of non-model organisms. Heredity 2011, 107, 1-15. [CrossRef]

182. McCormack, J.E.; Hird, S.M.; Zellmer, A.J.; Carstens, B.C.; Brumfield, R.T. Applications of next-generation sequencing to phylogeography and phylogenetics. Mol. Phylogenet. Evol. 2013, 66, 526-538. [CrossRef] [PubMed]

183. Shafer, A.B.A.; Peart, C.R.; Tusso, S.; Maayan, I.; Brelsford, A.; Wheat, C.W.; Wolf, J.B.W. Bioinformatic processing of RAD-seq data dramatically impacts downstream population genetic inference. Methods Ecol. Evol. 2017, 8, 907-917. [CrossRef]

184. Wang, S.; Meyer, E.; McKay, J.K.; Matz, M. V 2b-RAD: A simple and flexible method for genome-wide genotyping. Nat. Methods 2012, 9, 808-810. [CrossRef] [PubMed]

185. Wang, S.; Liu, P.; Lv, J.; Li, Y.; Cheng, T.; Zhang, L.; Xia, Y.; Sun, H.; Hu, X.; Bao, Z. Serial sequencing of isolength RAD tags for cost-efficient genome-wide profiling of genetic and epigenetic variations. Nat. Protoc. 2016, 11, 2189-2200. [CrossRef] [PubMed]

186. Peterson, B.K.; Weber, J.N.; Kay, E.H.; Fisher, H.S.; Hoekstra, H.E. Double digest RADseq: An inexpensive method for de novo SNP discovery and genotyping in model and non-model species. PLoS ONE 2012, 7, e37135. [CrossRef]

187. Andrews, K.R.; Good, J.M.; Miller, M.R.; Luikart, G.; Hohenlohe, P.A. Harnessing the power of RADseq for ecological and evolutionary genomics. Nat. Rev. Conserv. 2016, 17, 81. [CrossRef]

188. Olsen, J.L.; Rouzé, P.; Verhelst, B.; Lin, Y.C.; Bayer, T.; Collen, J.; Dattolo, E.; De Paoli, E.; Dittami, S.; Maumus, F.; et al. The genome of the seagrass Zostera marina reveals angiosperm adaptation to the sea. Nature 2016, 530, 331-335. [CrossRef] [PubMed]

189. Lee, H.; Golicz, A.A.; Bayer, P.E.; Jiao, Y.; Tang, H.; Paterson, A.H.; Sablok, G.; Krishnaraj, R.R.; Chan, C.-K.K.; Batley, J.; et al. The Genome of a Southern Hemisphere Seagrass Species (Zostera muelleri). Plant. Physiol. 2016, 172, 272-283. [CrossRef] [PubMed]

190. Phair, N.L.; Toonen, R.J.; Knapp, I.; Von der Heyden, S. Shared genomic outliers across two divergent population clusters of a highly threatened seagrass. PeerJ 2019, 7, e6806. [CrossRef]

191. Phair, N.L.; Toonen, R.J.; Knapp, I.S.S.; Von der Heyden, S. Anthropogenic pressures negatively impact genomic diversity of the vulnerable seagrass Zostera capensis. J. Environ. Manag. 2020, 255, 109831. [CrossRef]

192. Paun, O.; Verhoeven, K.J.F.; Richards, C.L. Opportunities and limitations of reduced representation bisulfite sequencing in plant ecological epigenomics. N. Phytol. 2019, 221, 738-742. [CrossRef]

193. Olova, N.; Krueger, F.; Andrews, S.; Oxley, D.; Berrens, R.V.; Branco, M.R.; Reik, W. Comparison of whole-genome bisulfite sequencing library preparation strategies identifies sources of biases affecting DNA methylation data. Genom. Biol. 2018, 19, 1-19. [CrossRef] [PubMed]

194. Wang, S.; Lv, J.; Zhang, L.; Dou, J.; Sun, Y.; Li, X.; Fu, X.; Dou, H.; Mao, J.; Hu, X. MethylRAD: A simple and scalable method for genome-wide DNA methylation profiling using methylation-dependent restriction enzymes. Open Biol. 2015, 5, 150130. [CrossRef] [PubMed]

195. Van Gurp, T.P.; Wagemaker, N.C.A.M.; Wouters, B.; Vergeer, P.; Ouborg, J.N.J.; Verhoeven, K.J.F. epiGBS: Reference-free reduced representation bisulfite sequencing. Nat. Methods 2016, 13, 322-324. [CrossRef] [PubMed]

196. Trucchi, E.; Mazzarella, A.B.; Gilfillan, G.D.; Lorenzo, M.T.; Schönswetter, P.; Paun, O. Bs RAD seq: Screening DNA methylation in natural populations of non-model species. Mol. Ecol. 2016, 25, 1697-1713. [CrossRef] 
197. Williams, A.V.; Nevill, P.G.; Krauss, S.L. Next generation restoration genetics: Applications and opportunities. Trends Plant. Sci. 2014, 19, 529-537. [CrossRef] [PubMed]

198. Corlett, R.T. Restoration, reintroduction, and rewilding in a changing world. Trends Ecol. Evol. 2016, 31, 453-462. [CrossRef]

199. Montalvo, A.M.; Williams, S.L.; Rice, K.J.; Buchmann, S.L.; Cory, C.; Handel, S.N.; Nabhan, G.P.; Primack, R.; Robichaux, R.H. Restoration biology: A population biology perspective. Restor. Ecol. 1997, 5, 277-290. [CrossRef] 